\title{
Teachers' Perceptions on Environmental Citizenship: A Systematic Review of the Literature
}

\author{
Yiannis Georgiou ${ }^{1,2}\left(\mathbb{D}\right.$, Andreas Ch. Hadjichambis ${ }^{1,2, *(\mathbb{D})}$ and Demetra Hadjichambi ${ }^{1,2}$ (I) \\ 1 Cyprus Centre for Environmental Research \& Education (CYCERE), Limassol 3304, Cyprus; \\ yg.kykpee@gmail.com (Y.G.); d.hadjichambi@cytanet.com.cy (D.H.) \\ 2 Cyprus Ministry of Education, Culture, Sport \& Youth (MOEC), Nicosia 1434, Cyprus \\ * Correspondence: a.hadjichambis@cytanet.com.cy
}

Citation: Georgiou, Y.;

Hadjichambis, A.C.; Hadjichambi, D. Teachers' Perceptions on

Environmental Citizenship: A Systematic Review of the Literature. Sustainability 2021, 13, 2622. https:// doi.org/10.3390/su13052622

Academic Editor:

David González-Gómez

Received: 31 January 2021

Accepted: 23 February 2021

Published: 1 March 2021

Publisher's Note: MDPI stays neutral with regard to jurisdictional claims in published maps and institutional affiliations.

Copyright: (c) 2021 by the authors. Licensee MDPI, Basel, Switzerland. This article is an open access article distributed under the terms and conditions of the Creative Commons Attribution (CC BY) license (https:// creativecommons.org/licenses/by/ $4.0 /)$.

\begin{abstract}
As we are living amid an unprecedent environmental crisis, the need for schools to empower students into environmental citizenship is intensifying. Teachers are considered as the main driving force in fostering students' environmental citizenship. However, a critical question is how teachers conceive environmental citizenship and whether their perceptions of environmental citizenship are well-informed. There is an urgent need to investigate teachers' perceptions, considering their crucial role in the formation of students' environmental citizenship. This study examines teachers' perceptions of environmental citizenship through a systematic review and thematic analysis of relevant empirical studies. The selected studies $(n=16)$ were published in peer-reviewed journals during the timespan of the last twenty-five (25) years (1995-2020). The thematic findings of this review revealed that teachers' perceptions: (a) manifest a relatively decreased understanding of environmental citizenship, (b) are narrowed down to the local scale, individual dimension and private sphere, (c) affect teaching practices, (d) are multi-dimensional, defined by inter-related components, (e) vary according to teachers' educational/cultural background and personal identity, (f) affect other environmental constructs defining teachers' professional identity, $(\mathrm{g})$ can be enhanced during teacher education, (h) can be also improved during professional development initiatives. These findings bear significant implications for researchers, policymakers, as well as for teacher educators in the field of Environmental Education.
\end{abstract}

Keywords: teachers' perceptions; environmental citizenship; teacher education; Environmental Education; Education for Environmental Citizenship (EEC)

\section{Introduction}

We are currently witnessing an unprecedented environmental crisis. Environmental problems such as deforestation, climate change and ice melt, pollution, waste disposal, loss of biodiversity and depletion of resources are just some of the main challenges that we must deal with [1,2]. Taking into account the scale as well as the impact of these environmental problems, we are now more than ever in need of empowered, active young citizens, who may contribute to the mitigation of these extreme socioenvironmental issues.

Environmental Education could serve as the vehicle towards this goal, as action can be found deeply rooted in its framework. Focusing on the 1977 Tbilisi Declaration, Environmental Education has emphasized, for instance, the development of students who are not only aware of environmental problems, but who also adopt pro-environmental behaviors. In particular, Environmental Education has focused on promoting learners' "practical skills required in the devising and application of effective solutions to environmental problems" [3] (p. 14). Many scholars have also previously supported the notion that the ultimate goal of Environmental Education should be to support students in acting as informed and empowered citizens [4-8].

The aforementioned aims of Environmental Education are well-reflected within the concept of Environmental Citizenship. Environmental citizenship is not a novel concept; 
however, the concept has started to become more popular in the field of education in recent years, given that prior educational research on environmental citizenship was sparse and fragmented, due to the political, economic and societal dimensions of the concept. According to Hadjichambis and Reis [2], the fragmented nature of the research findings related to environmental citizenship prohibits their effective integration into good practices and policy frameworks in the educational context as well as a well-informed conceptualization of what environmental citizenship entails. Despite the fragmentation of prior research, there is agreement that an environmental citizen is a person who is aware of environmental problems, has relevant environmental knowledge and skills, understands cause-response relationships in the socioecological systems and undertakes responsible environmental action [9,10]. In turn, Environmental Education has been argued to be a fundamental tool that can effectively contribute to the adoption of proenvironmental behaviors, which can eventually be translated into aspects of environmental citizenship [11,12].

However, in order to foster Education for Environmental Citizenship in schools, there is a need to provide constant guidance and extensive training for teachers in order to improve their environmental knowledge, awareness, dispositions and strategies $[13,14]$. Undoubtedly, teachers play a crucial role in promoting their students' environmental citizenship, particularly their knowledge, attitudes, values, beliefs and actions towards the environment [15-17]. It is therefore essential to determine how current and prospective teachers perceive the concept of "environmental citizenship" [18] and, subsequently, the degree to which they are prepared to take up Education for Environmental Citizenship. Whether teachers implement Education for Environmental Citizenship in the classroom is dependent upon their interest, knowledge and skills [6]. The overall goal of the current study is to explore teachers' perceptions of environmental citizenship by means of a systematic literature review. This overarching goal is distributed and further elaborated in the following research questions, guiding this review:

1. How do teachers conceive environmental citizenship?

2. What are the main characteristics of teachers' perceptions of environmental citizenship?

3. What is the impact of teachers' perceptions of environmental citizenship on their professional identity?

4. How can teachers' perceptions of environmental citizenship be enhanced?

The rest of the manuscript continues by defining Education for Environmental Citizenship (EEC) and explicating the need for investigating teachers' perceptions of environmental citizenship. We then present the methodology of this review study as well as a synopsis and synthesis of our findings, followed by a set of guidelines for future research and practice in the field.

\section{Education for Environmental Citizenship}

Despite its importance, environmental citizenship has received limited exploration so far, until the last few years [19]. On one hand, this could be attributed to the conceptual complexity of environmental citizenship, as well as to its relations with more established constructs (i.e., environmental behavior, environmental attitudes, environmental literacy, environmental knowledge, awareness and sustainability), which have been often used as complements or substitutes [20]. On the other hand, environmental citizenship has political, economic and societal dimensions, which have contributed to the fragmentation of relevant research. This can also justify the use of the concept under different labels, such as "sustainable citizenship" [21], "green citizenship" [18], "ecological citizenship" [22] or even "global citizenship" and "active citizenship", even though the two latter terms are considered as broader concepts, which encompass a broader sense of citizenship.

Although research related to environmental citizenship is sparse and has been thinly spread across different research disciplines, various scholars and theorists have accumulated and agreed upon on its main attributes $[4,19]$. For instance, it has been argued that 
environmental citizenship encompasses ecological literacy with a focus on the understanding of socioecological issues $[23,24]$, the rights and the obligations of citizens within political communities $[25,26]$, awareness of personal values with respect to the environment and the ability to connect these values with knowledge and skills to take environmentally-oriented decisions [4,27], as well as civic engagement and participation to address environmental problems [28,29]. In its essence, environmental citizenship has emerged as an umbrella concept which includes an amalgam of characteristics, such as the skills, knowledge, attitudes, values and beliefs required to address environmental problems [30], as well as the competences needed for civic engagement and active participation in societies [20].

Educating and empowering young people to become environmental citizens is crucial for addressing current environmental issues and it is a prerequisite of sustainability, which is identified as one of the priorities worldwide [31,32]. However, environmental citizenship, as a comprehensive concept, has been elucidated from collective research efforts, especially in the field of Environmental Education. It is only recently that the concept has started to receive the attention it deserves, in times of environmental urgency. For instance, more than 130 researchers and scholars from 39 countries have joined their forces, during the last two years, in the context of the European Network for Environmental Citizenship (ENEC) [33], trying to establish an inclusive definition of "Education for Environmental Citizenship". This review study adopts this definition, as it provides a concrete basis for the conceptualization of environmental citizenship for 21st century education, and it is briefly presented as follows:

"Education for Environmental Citizenship' is defined as the type of education that cultivates a coherent and adequate body of knowledge as well as the necessary skills, values, attitudes and competences that an Environmental Citizen should be equipped with in order to be able to act and participate in society as an agent of change in the private and public sphere on a local, national and global scale, through individual and collective actions in the direction of solving contemporary environmental problems, preventing the creation of new environmental problems, in achieving sustainability as well as developing a healthy relationship with nature. Education for Environmental Citizenship is important to empower citizens to practice their environmental rights and duties, as well as to identify the underlying structural causes of environmental degradation and environmental problems, develop the willingness and the competences for critical and active engagement and civic participation to address those structural causes and act individually and collectively within democratic means, taking into account the inter-and intra-generational justice".

According to this definition, the ultimate goal of Education for Environmental Citizenship (EEC) is to equip students with a coherent corpus of knowledge, skills, values, attitudes and active behaviors, in order to act pro-environmentally, as "agents of change", as well as to help them understand the urgency of environmental issues and to integrate proenvironmental actions into the core of their political participation and environmental citizenship expressions. Toward this direction, Hadjichambis and Paraskeva-Hadjichambi [20], in their recent work undertaken within the European Network for Environmental Citizenship (ENEC), have attempted to define the pedagogical landscape in which EEC is situated and they proposed eight pedagogical approaches which may, partially, contribute to EEC, as follows: (a) Place-based learning, (b) Problem-based learning, (c) Civic ecology education, (d) Pedagogy for eco-justice, (e) Action competence learning, (f) Community service learning, (g) Participatory action research, and (h) Socio-scientific inquiry-based learning. However, as explained, while the above pedagogical approaches can contribute to EEC, none of them alone can promote the scope and aims of the EEC [34]. Going a step further, Hadjichambis and Paraskeva-Hadjichambi [20] have also summarized the intended outputs of EEC, as follows: (a) Solving current environmental problems, (b) Preventing new environmental problems, (c) Achieving sustainability, (d) Developing healthy relationships with nature, (e) Practicing environmental rights and duties, (f) Identifying structural causes of environmental problems, (g) Achieving critical and active engagement 
and civic participation, and (h) Promoting inter- and intra-generational justice. Finally, they have also highlighted that the potential actions which an environmental citizen may undertake are of two dimensions (individual and collective), these actions could be applied in different spheres (private and public spheres), and they may have an impact at different scales (local, national or global). More information is available at the ENEC official website: https: / / enec-cost.eu/ (accessed on 18 December 2020) [34].

An overview of the EEC model is provided in Figure 1.

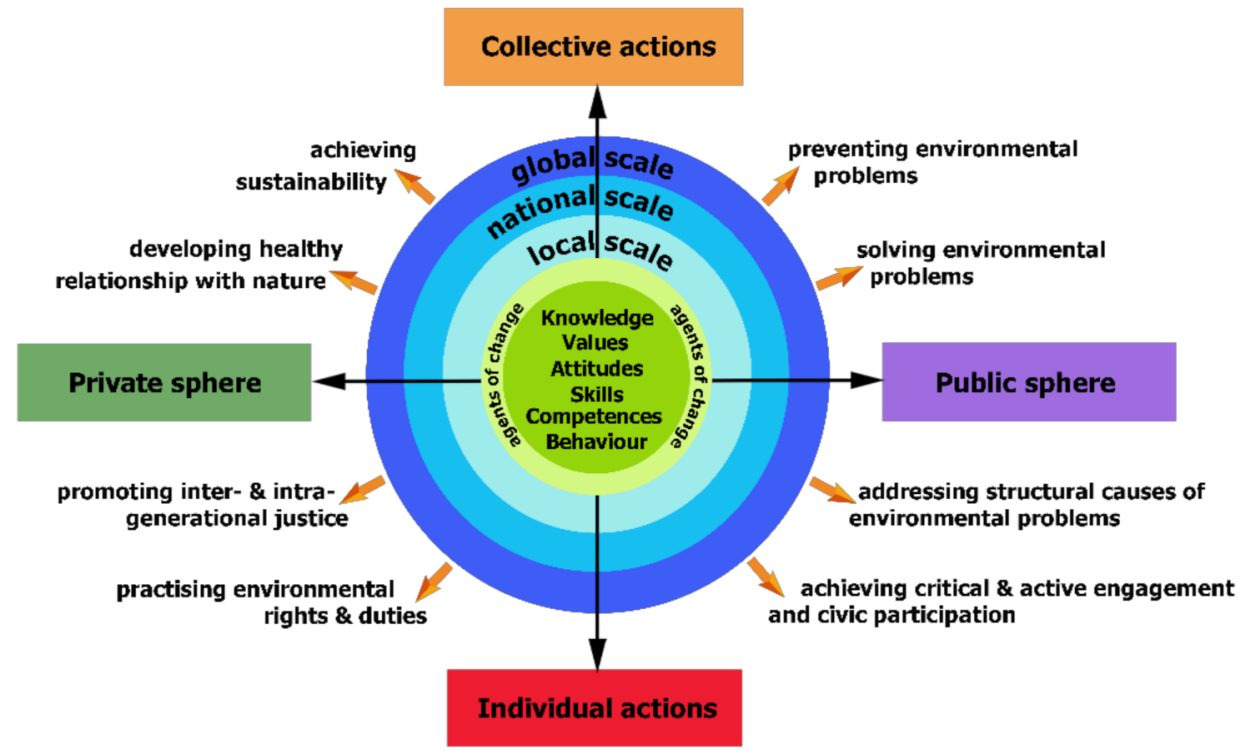

Figure 1. The Education for Environmental Citizenship (EEC) model (Source: Hadjichambis, A. Ch. \& Paraskeva-Hadjichambi D. (2020). Education for Environmental Citizenship: the pedagogical approach. In: A. Ch. Hadjichambis, P. Reis, D. Paraskeva-Hadjichambi et al. (Eds.) Conceptualizing Environmental Citizenship for 21st Century Education (pp. 260-290). Cham, Switzerland: Springer.).

It is worthwhile to briefly describe the relationship between Environmental Education and Education for Environmental Citizenship (EEC). It has been supported by many studies on Environmental Education that it contributes to the empowerment of well-informed citizens, e.g., [7], and that Environmental Education can contribute to the promotion of environmental citizenship, e.g., [35] Although there are cases in the Environmental Education literature in which this is verified, e.g., [36], it is an unquestionable fact that this is not the mainstream in Environmental Education. Many researchers have argued, for instance, that there is still disagreement and different approaches as to what the main goals, objectives and outcomes of Environmental Education are and how they can be achieved, e.g., [37]. In addition, there is a lot of criticism of the individualistic approach in Environmental Education, aimed mainly at personal behavioral changes, e.g., [38]. In many Environmental Education programs, there is a lack of collective actions both in the private but much more in the public sphere. On the other hand, Education for Environmental Citizenship emphasizes both the individual and the collective dimensions of environmental citizenship but also actions in the private and public spheres which will not be limited only to a local scale but also to the national and on a global scale. All these are emphasized with a deep civic participation and an active, critical and democratic engagement of the citizens in the formulation of the policies and in the decision-making for effective confrontation of the deeper structural causes that create environmental problems. In addition, Education for Environmental Citizenship also attaches great importance to environmental and social justice, including the exercise of environmental rights and duties, as well as to inter- and intra-generational justice. This clarity and integration on the scope, outputs, dimensions, spheres and scales never was at the heart of our educational systems. 
Despite these promising research steps, EEC can take place only if teachers are deeply aware of what environmental citizenship entails and are able to put forward successfully these pedagogical approaches. Put simply, classroom teachers are in a unique position to develop student skills and knowledge of environmental citizenship and sustainable environmental behavior through their teaching [39]. In order for this to happen, though, it is essential to ensure that current and prospective teachers' conceptions of environmental citizenship are accurate and well-informed [18]. Responding to this call, the present study reviews and synthesizes the current literature presenting qualitative and quantitative explorations of teachers' perceptions of environmental citizenship. Prior review studies in the field have focused on teacher conceptions of environmental/sustainability education, on their related teaching practices as well as on environmental teachers' training and professional development [40-43]. However, according to our knowledge, there are no published review studies so far dedicated to the examination of teachers' perceptions of environmental citizenship. Our study aims to contribute to this research gap by investigating teachers' perceptions of environmental citizenship, through a systematic review of relevant empirical studies in the field.

\section{Methods}

\subsection{Data Collection}

The studies analyzed in this literature review covered empirical and theoretical research published during the last twenty-five years, from 1995 to 2020.

The retrieval of the reviewed studies followed the PRISMA standards for Systematic Literature Reviews (http:/ / prisma-statement.org/) (accessed on 30 September 2020) [44] and was based on a multi-step procedure comprising three sequential stages, as follows: (a) Identification, (b) Screening, and (c) Eligibility (Figure 2).

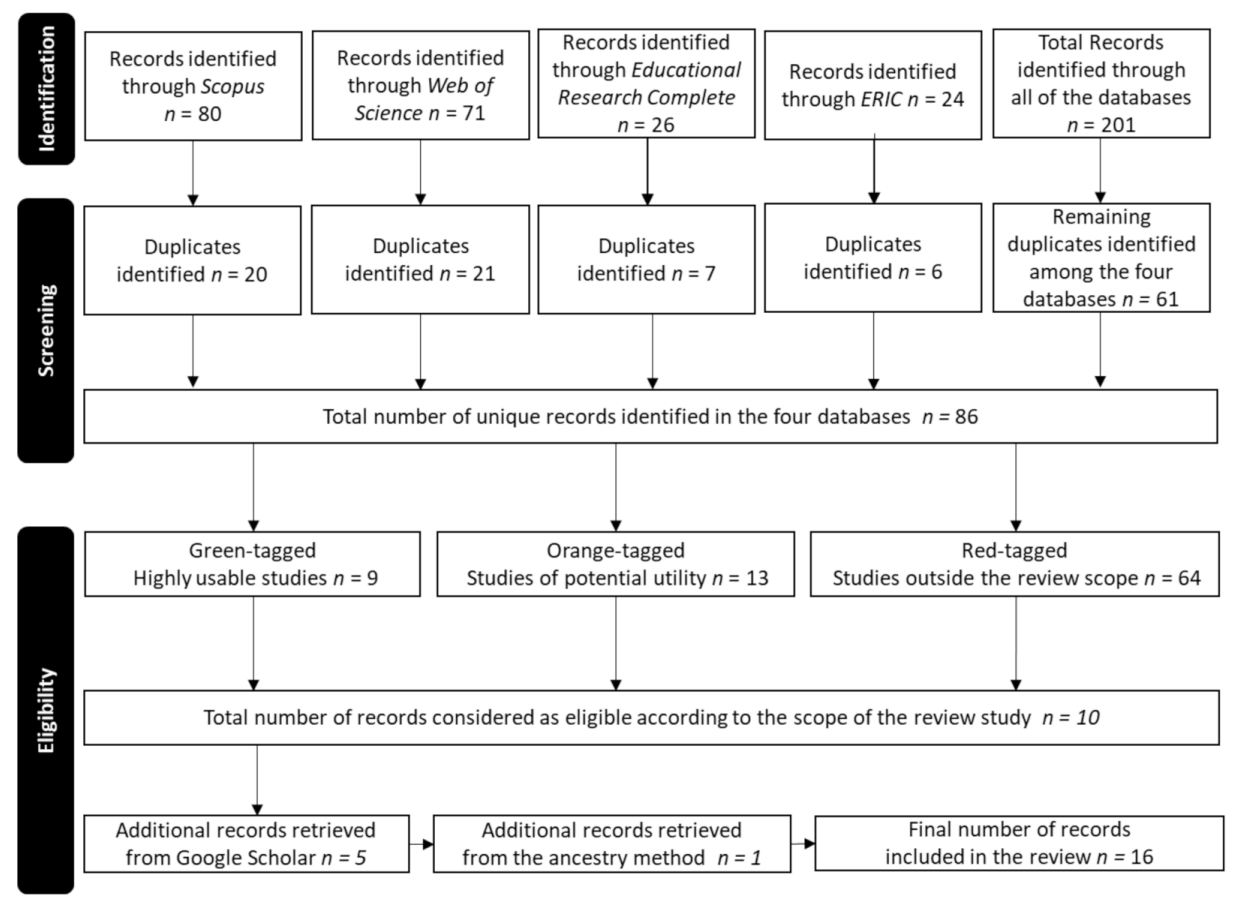

Figure 2. Flow diagram illustrating the review selection process.

Initially, in the first step, the published literature was surveyed using four electronic databases: Scopus, Web of Science, Education Research Complete (via EBSCO) and ERIC, which are considered among the most enriched and popular academic databases. The retrieving keywords included the terms, "Environmental citizenship" OR "Environmental citizen", "Ecological citizenship" OR "Ecological citizen", "Green citizenship" OR "Green citizen", "Sustainability citizenship" OR "Sustainable citizen", in combination with the terms "Teachers", 
"Educators", "Perceptions" and "Conceptions". This ensured that the retrieved results would be mostly focused on pre-/in-service teachers' perceptions of environmental citizenship. After performing all 32 possible combinations, we retrieved a total of 201 records from the four databases.

In the second step, these records were screened and both internal duplicates as well as duplicates between the four databases $(n=115)$ were removed, resulting in a total of 86 records. In the third step, the remaining records $(n=86)$ were filtered, to identify their eligibility, on the basis of four selection criteria. In particular, to be included in the corpus of the reviewed studies, a study ought to have met a number of criteria, as follows: (1) Source type: The study should have been published in English, as a full paper in a peer-reviewed academic journal, between 1995 and 2020; (2) Research focus: The study should be related to teachers' perceptions on environmental citizenship; (3) Research methods: The study should be empirical, providing primary data derived from quantitative, qualitative or mixed designs; (4) Participants: The study participants should be in-service or pre-service teachers.

More specifically, the title, abstract and keywords of the retained, from step 1 and 2 , studies $(n=86)$ were filtered according to the aforementioned inclusion criteria. As part of this process, the studies were evaluated in relation to their eligibility, using the following color coding: (a) Green-tagging, for highly usable studies aligned with the criteria posed, (b) Red-tagging for studies outside the review scope, not aligned with the criteria posed, and (c) Orange-tagging for studies of potential utility, given that these studies seemed quite relevant to the scope of this review, but it was not absolutely clear from their title, abstract and keywords whether all the inclusion criteria were met. In this latter case, full-text versions of the studies were also obtained, read and filtered, in order to confirm whether these studies were aligned with the criteria posed or not. This final selection process resulted in 10 publications.

This initial corpus was enriched with an additional search using Google Scholar by combining the same keywords as well as by using the broader conceptual combinations "global citizenship - teachers-environment" and "active citizenship-teachersenvironment", focusing on the most prominent hits, which resulted in five additional empirical studies. Finally, the ancestry method [45] was also adopted, according to which we searched the references of the identified research articles for empirical studies that could be included in the present review. This process yielded one (1) additional article. Overall, a total of sixteen $(n=16)$ empirical studies met all the inclusion criteria and were selected for this review.

\subsection{Data Analysis}

The data collected from the empirical studies, included in this review paper, were analyzed using thematic analysis [46-48]. Thematic analysis was also adopted for similar purposes in prior review studies, which focused on the examination of teachers' perceptions of other concepts (e.g., creativity, STEM education) $[49,50]$. Thematic analysis is a qualitative analytic method for "identifying, analyzing, and reporting patterns (themes) within data" [47] (p. 79). In this method, each theme captures and presents important information about the data.

The thematic analysis undertaken proceeded through six phases. The first phase involved becoming familiar with the data; in the current study, familiarity with the data was initiated during the data collection process and the eligibility phase of the PRISMA methodology and was completed with a thorough reading of the selected empirical studies, included in this review. The second phase entailed generating initial codes, which in our study comprised the data extraction process. To generate the initial codes, we developed a coding scheme to extract the key data from the 16 reviewed studies. The coding scheme variables included the country and the year in which the study was conducted, the research goals of the study, sample attributes (e.g., number of teachers, grade level and subject taught, in-service or pre-service status), training attributes in case of training interventions 
to enhance teachers' perceptions (e.g., training approach, type of activities, professional development or teacher education context, duration), research design, data collection methods and findings.

The third phase included an initial search for themes within the findings of the review studies. As part of this phase, the research questions of this review study guided the searching and classification of themes across four broad categories, as follows: (a) Conceptualization (RQ1: How do teachers perceive environmental citizenship?), (b) Characteristics (RQ2: What is the nature of teachers' perceptions of environmental citizenship?), (c) Impact (What is the impact of teachers' environmental citizenship perceptions on their professional identity?), and (d) Enhancement (Whether and how can teachers' perceptions of environmental citizenship be enhanced?). As part of this phase, the reviewed studies were analyzed, and relevant text segments were extracted and placed into one of the aforementioned categories. Table 1 provides a definition of the categories guiding the thematic analysis.

Table 1. Definition of the categories guiding the thematic analysis.

\begin{tabular}{|c|c|c|}
\hline & Categories & Definition \\
\hline 1 & Conceptualization & $\begin{array}{l}\text { This category refers to the way teachers perceive both } \\
\text { environmental citizenship as well as the potential actions which } \\
\text { an environmental citizen may undertake in terms of dimensions } \\
\text { (individual and collective), spheres (private and public spheres) } \\
\text { and impact at different scales (local, national or global). }\end{array}$ \\
\hline 2 & Characteristics & $\begin{array}{l}\text { This category refers to the characteristics of the environmental } \\
\text { citizenship perceptions, focusing on their main components as } \\
\text { well as on their subjective nature. }\end{array}$ \\
\hline 3 & Impact & $\begin{array}{l}\text { This category refers to the impact of teachers' perceptions of } \\
\text { environmental citizenship on teaching practices as well as on } \\
\text { teachers' professional identity. }\end{array}$ \\
\hline 4 & Enhancement & $\begin{array}{l}\text { This category refers to the enhancement of teachers' } \\
\text { perceptions in the context of teacher education or professional } \\
\text { development programs. }\end{array}$ \\
\hline
\end{tabular}

The fourth phase included the reviewing and checking of the themes in relation to the coded excerpts, while the fifth phase included the finalization and naming of the themes. As part of these phases, the authors elaborated collaboratively on the aforementioned classifying categories and identified two main themes per category, capturing more finetuned information about the analyzed findings of the reviewed studies. Finally, the sixth phase was the production of a concise report, taking into account all the categories and the emerging themes per category. This report is presented in the following section of this review study.

\section{Findings}

The empirical studies reviewed for this synthesis ranged in publication dates from 1995 to 2020. Only one study was published between 1995 and 2000 (6.3\%), two studies were published between 2001 and 2010 (12.5\%), while another two studies were published from 2011 to 2015 (12.5\%). A considerable peak in the published studies $(n=11,69 \%)$ can be observed during the last five years (2015-2020), indicating the increasing interest in the topic. The research topic has been investigated globally, in Australia, China, Egypt, Israel, Finland, Lebanon, Turkey, the United Kingdom and the United States. The majority of the studies took the form of qualitative case studies, while the rest of them adopted other research designs, such as quasi-experimental design, relational research methods, quantitative research methods or mixed methods. An overview of the empirical studies reviewed for this synthesis is presented in Table 2 . 
Table 2. Summary of reviewed studies.

\# $\quad$ Author(s)/Year $\quad$ Country $\quad$ Research Goals $\quad$ Research Design $\quad$ Sample Data Collection

Aarnio-

1 Linnanvuori,

2019
To investigate teachers perceptions of environmental responsibility with a focus on environmental citizenship.
Qualitative

case study
13 in-service teachers

in secondary

education
- Interviews Major Findings

Almost all the in-service teachers mentioned environmental citizenship as an integral part of environmental responsibility. However, teachers conceptualized environmental citizenship on the basis of individualization rather than on the basis of collectiveness. In addition, while the participating teachers were well aware of various environmental citizenship actions, they perceived their students' range of action possibilities as particularly narrow.

To evaluate the impact of an Environmental Education

course, tasking pre-service teachers to investigate and take action with respect to an environmental issue (in the context of a community-based project), on teachers' perceptions and practices of

environmental citizenship.

3 Avriel-Avni \& Israel Gan, 2019

To enhance pre-service teachers' perceptions of environmental citizenship by using the field mapping approach.

\section{Action research 24 in-service teachers}

- In-service teachers' field maps of action as "conceptual maps"
The community-based projects enacted during

- Teachers' artifacts (from their field work)

- Interviews the environmental course enhanced teachers' conceptions of environmental citizenship.

During their fieldwork, and as acts of

environmental citizenship, the teachers strove to find solutions for the environmental problems

they encountered in their communities.

The use of field maps helped the pre-service teachers to better understand the complexity of a social-ecological system as well as to realize their role, as active citizens within it, thus promoting their understanding of environmental citizenship.

Many pre-service teachers do not have the pedagogical content knowledge and skills to

To explore ways in which some examples of children's literature can be used to assist pre-service

4 Bradberry, 2013 Australia teachers to develop children's environmental citizenship and understandings of an ecologically sustainable future. $\begin{array}{ll}\text { Qualitative case } & 5 \text { tutors (and } 140 \\ \text { study } & \text { pre-service teachers) }\end{array}$

- $\quad$ Surveys
- Reflective diarie Group interviews achieve environmental sustainability. Children's literature on ecological issues can be utilized in producing future teachers able to transform their students into actively participatory human beings, via fostering their environmental literacy and environmental citizenship. 
Table 2. Cont.

\begin{tabular}{|c|c|c|c|c|c|}
\hline Author(s)/Year & Country & Research Goals & Research Design & Sample & Data Collection \\
\hline
\end{tabular}

To investigate the relationship of environmental citizenship with

5 Bulut, 2019

Turkey the sustaina

awareness levels of

Relational

387 pre-service

pre-service teachers. research methods teachers attending

social studies
- Questionnaires
To explore the meaning of environmental citizenship

education for

pre-service teachers.
93 pre-service

teachers, training to

Quantitative

research methods become secondary school teachers
To evaluate the impact of an Environmental Education

7 Chaya \& Ali, 2016 Lebanon course, which included

project-based learning

on teachers

environmental citizenship.
222 pre-service

teachers $(162$

Mixed methods

undergraduate

students and 60 post-

graduate students)
- Questionnaire

- Projects

(n)

ection

The sustainable development awareness and environmental citizenship levels of females were higher when compared to male

pre-service teachers. Both environmental citizenship and sustainable development awareness levels of the pre-service teachers increased as the grade of the pre-service teachers increased from the freshmen to the senior level. Finally, there was a positive correlation between environmental citizenship and sustainable development awareness levels of the participants.

Environmental citizenship is inadequately conceptualized by the pre-service teachers. A few pre-service teachers gave responses that were categorized as clearly providing the definition and/or aims of environmental citizenship. While the pre-service teachers expressed the need for taking action, they over-emphasized the importance of direct personal action for the environment (largely recycling), neglecting other forms and types of environmental citizenship actions.

Before the course, the pre-service teachers had low to average knowledge, practice and attitudes towards environmental citizenship. They showed devalued commitment towards environmental citizenship, which was revealed by the ignorance of their responsibility towards the environment. After the course, the teachers' knowledge, practice and attitudes towards environmental citizenship were significantly increased. 
Table 2. Cont.

\begin{tabular}{|c|c|c|c|c|c|c|c|}
\hline$\#$ & Author(s)/Year & Country & Research Goals & Research Design & Sample & Data Collection & Major Findings \\
\hline 8 & Gal \& Gan, 2020 & Israel & $\begin{array}{l}\text { To evaluate the impact of an } \\
\text { Environmental Education } \\
\text { course, which aimed at fostering } \\
\text { pre-service teachers' } \\
\text { environmental understanding } \\
\text { and environmental citizenship. }\end{array}$ & $\begin{array}{l}\text { Qualitative } \\
\text { case study }\end{array}$ & $\begin{array}{l}20 \text { pre-service } \\
\text { teachers }\end{array}$ & $\begin{array}{ll}\text { - } & \text { Essays } \\
\text { - } & \text { Assignments } \\
\text { - } & \text { Reflections } \\
& \text { Interviews }\end{array}$ & $\begin{array}{l}\text { Prior to the course, the pre-service teachers did } \\
\text { not display a deep understanding of } \\
\text { social-ecological systems or pro-environmental } \\
\text { actions. The course increased teachers' } \\
\text { understanding of social-ecological systems and } \\
\text { encouraged most of them to act as agents } \\
\text { of change. }\end{array}$ \\
\hline 9 & Gooch et al., 2008 & Australia & $\begin{array}{l}\text { To analyze environmentally } \\
\text { focused integrated unit plans, } \\
\text { developed and implemented by } \\
\text { pre-service teachers, to } \\
\text { determine the extent to which } \\
\text { they contained concepts } \\
\text { that promoted } \\
\text { environmental citizenship. }\end{array}$ & $\begin{array}{l}\text { Content analysis } \\
\text { methods }\end{array}$ & $\begin{array}{l}46 \text { pre-service } \\
\text { teachers trained to } \\
\text { become teachers in } \\
\text { primary education }\end{array}$ & $\begin{array}{ll}- & \text { Integrated } \\
& \text { lesson plans }\end{array}$ & $\begin{array}{l}\text { The analyzed lesson plans, in many cases, were } \\
\text { lacking any action-oriented knowledge. These } \\
\text { findings suggest that pre-service teachers need } \\
\text { support for teaching, learning and acting } \\
\text { responsibly in relation to complex environmental } \\
\text { issues. The teachers should receive guidance in } \\
\text { order to be able to empower their students as } \\
\text { well as to promote their } \\
\text { environmental citizenship. }\end{array}$ \\
\hline 10 & Green et al., 2016 & US & $\begin{array}{l}\text { To explore how participating in } \\
\text { a political environmental action } \\
\text { project influenced teachers' } \\
\text { environmental citizenship. }\end{array}$ & $\begin{array}{l}\text { Qualitative } \\
\text { case study }\end{array}$ & $\begin{array}{l}7 \text { pre-service teachers } \\
\text { (undergraduate } \\
\text { students) }\end{array}$ & $\begin{array}{ll}\text { - } & \text { Writing } \\
& \text { prompts } \\
\text { - } & \text { Group } \\
& \text { discussions } \\
\text { - } & \text { Emails } \\
\text { - } & \text { Focus groups } \\
\text { - } & \text { Observations }\end{array}$ & $\begin{array}{l}\text { At the end of the project, there was a growth in } \\
\text { the pre-service teachers' environmental } \\
\text { citizenship, including their self-efficacy, values, } \\
\text { awareness and ecological and civics literacy. The } \\
\text { pre-service teachers recognized energy } \\
\text { conservation as a socioenvironmental issue, with } \\
\text { local and global implications, and indicated their } \\
\text { professional commitment toward action-oriented } \\
\text { Environmental Education. }\end{array}$ \\
\hline 11 & Karatekin, 2019 & Turkey & $\begin{array}{l}\text { To identify the level of } \\
\text { environmental citizenship of } \\
\text { teachers as well as to investigate } \\
\text { the relationship between the } \\
\text { dimensions of environmental } \\
\text { citizenship and the mediating } \\
\text { role of curiosity about the } \\
\text { environment and the frequency } \\
\text { of participation in } \\
\text { environmental activities. }\end{array}$ & $\begin{array}{l}\text { Relational } \\
\text { research method }\end{array}$ & $\begin{array}{l}296 \text { in-service } \\
\text { teachers at secondary } \\
\text { education }\end{array}$ & - Questionnaires & $\begin{array}{l}\text { The teachers' environmental citizenship levels } \\
\text { were moderate to low in the dimension of civic } \\
\text { participation, moderate in the dimensions of } \\
\text { responsibility and sustainability and high in the } \\
\text { dimension of rights and justice. Teachers' } \\
\text { curiosity towards the environment as well as the } \\
\text { frequency of participation in environmental } \\
\text { activities positively predicted their } \\
\text { environmental citizenship. }\end{array}$ \\
\hline
\end{tabular}


Table 2. Cont. Author(s)/Year Country Research Goals Research Design Sample Data Collection Major Findings

To examine the influence of environmental citizenship

12 Lummis et al., $2016 \quad$ Australia and political solidarity on teachers' perceptions of sustainability.

\section{Qualitative \\ 18 pre-service}

case study

teachers
To evaluate the impact of a Professional Development

(PD) workshop on teachers' perceptions of environmental citizenship.
Quasi-

experimental design
94 in-service teachers in both primary and secondary education
- $\quad$ Pre-Post survey

- Follow-up questionnaire

To compare the perspectives

of Guangdong, Hong Kong and Minnesota in-service teachers on key citizen

14 Paige \& Cogan. 2002 US \& Chin

characteristics and

environmental concerns in

the context of a Citizenship

Education Project.

$\begin{array}{ll}\text { Quantitative } & 405 \text { in-service } \\ \text { research methods } & \text { teachers }\end{array}$

The findings revealed that the pre-service teachers' perceptions of sustainability were influenced by environmental citizenship and political solidarity concepts. However none of the teachers used these latter terms explicitly during their interviews. The teachers also mixed up some of their ideas within both environmental citizenship and political solidarity.

The PD workshop elicited a statistically significant improvement in teachers' perceptions overall as well as regarding all five components defining environmental citizenship: Ecological Literacy, Civics Literacy, Practical Wisdom, Values, and Self-Efficacy.

The results showed that there were areas of agreement as well as disagreement between the three populations, with teachers in Guangdong and Minnesota being the furthest apart on citizen characteristics and the closest together on environmental concerns.

At the end of the PD program, there was an

To evaluate the impact of a Professional Development (PD) program on teachers' environmental awareness, environmental citizenship and leadership.
Quasi-

experimental design
- Pre-Post 46 in-service teachers in pre-school education increase in teachers' environmental awareness, with the teachers exhibiting profound understanding, high values and a deep willingness to act. The teachers reported experiences of

empowerment-both on a personal level, and as educators and leaders. 
Table 2. Cont.

\# Author(s)/Year Country Research Goals

\section{Research Design}

Sample

To investigate the environmental

citizenship of pre-service

16 Ünal, 2019

Turkey teachers in terms of different

variables and to determine the

variables influencing the

environmental citizenship level.
Quantitative 318 pre-service

research methods teachers

- Questionnaires
Data Collection

\section{Major Findings}

The environmental citizenship levels of the

pre-service teachers did not differ significantly in

relation to their gender, mother's educational

attainment level, father's educational attainment

level, membership in non-governmental

organizations and membership in pre-service

teachers' organizations. Significant differences

were found due to the impact of pre-service

teachers' educational disciplines (departments)

and participation in social projects. 
The thematic analysis resulted in eight main themes-two themes per category (Conceptualization, Characteristics, Impact, Enhancement), which appeared across the reviewed articles. Table 3 presents the emerging themes as well as their frequency. Subsequently, we discuss and elaborate further on the themes derived from the analysis of the reviewed studies, per coding category.

Table 3. Frequency of the main themes per category as derived from the analyzed empirical studies.

\begin{tabular}{|c|c|c|c|c|}
\hline & Categories & & Themes of Teachers' Perceptions & Frequency \\
\hline \multirow{2}{*}{1} & \multirow{2}{*}{ Conceptualization } & $1 \mathrm{a}$ & $\begin{array}{l}\text {... manifest a relatively decreased understanding } \\
\text { of environmental citizenship }\end{array}$ & 10 \\
\hline & & $1 b$ & $\begin{array}{l}\ldots \text { are narrowed down to the local scale, } \\
\text { individual dimension and private sphere }\end{array}$ & 4 \\
\hline \multirow[b]{2}{*}{2} & \multirow[b]{2}{*}{ Characteristics } & $2 a$ & $\begin{array}{l}\ldots \text { are multi-dimensional; are defined by several } \\
\text { inter-related components }\end{array}$ & 3 \\
\hline & & $2 b$ & $\begin{array}{l}\text {... vary according to teachers' } \\
\text { educational/cultural background and personal } \\
\text { identity }\end{array}$ & 5 \\
\hline \multirow[b]{2}{*}{3} & \multirow[b]{2}{*}{ Impact } & $3 a$ & ... affect teaching practices & 4 \\
\hline & & $3 b$ & $\begin{array}{l}\ldots \text { affect other environmental constructs which } \\
\text { define teachers' professional identity }\end{array}$ & 2 \\
\hline \multirow[b]{2}{*}{4} & \multirow[b]{2}{*}{ Enhancement } & $4 a$ & ... can be enhanced during teacher education & 5 \\
\hline & & $4 \mathrm{~b}$ & $\begin{array}{l}\text {... can be further improved during professional } \\
\text { development initiatives }\end{array}$ & 3 \\
\hline
\end{tabular}

\subsection{Conceptualization}

The thematic analysis of the reviewed studies resulted in two main themes related to teachers' conceptualizations of environmental citizenship. Firstly, according to their perceptions, teachers manifested a relatively decreased understanding of environmental citizenship (Theme \#1, Table 3). Secondly, teachers' perceptions of environmental citizenship were narrowed down to the local scale, individual dimension and private sphere (Theme \#2, Table 3). Below, we present each theme, providing supporting evidence from the reviewed studies.

\subsubsection{Teachers' Perceptions Manifest a Relatively Decreased Understanding of Environmental Citizenship}

The majority of the reviewed papers have emphasized that teachers' understanding of environmental citizenship is relatively limited [6,18,39,51-57]. Focusing on both pre- and in-service teachers' perceptions, it seems that environmental citizenship is not well defined, but it remains a largely unexplored concept.

For instance, the oldest study which has been included in this review belongs to Campell and Davies [18] and has focused on the investigation of pre-service teachers' perceptions of environmental citizenship. As this study has found, only a few pre-service teachers were able to provide clear definitions of what environmental citizenship is or to define the aims of environmental citizenship. Similar findings were presented by the more recent study of Chaya and Ali [53], who reported that pre-service teachers had low to average knowledge, practice and attitudes towards sustainable development and environmental citizenship. In particular, the participating pre-service teachers showed devalued commitment towards environmental citizenship, which was revealed by the ignorance of their responsibility towards the environment.

Likewise, in a different study, Lummis et al. [56] have supported the notion that some of the pre-service teachers who participated in their study seemed to have some initial ideas about what environmental citizenship is and what it entails, by highlighting the issues of preservation, reducing ecological strain and responsibility. However, as they 
found, the concept of environmental citizenship was mostly situated in the subconscious of the pre-service teachers, as none of the participants used the term during the interviews. In addition, they reported that pre-service teachers' perceptions of environmental citizenship were fragmented and mixed up with ideas related to political solidarity.

4.1.2. Teachers' Perceptions of Environmental Citizenship Are Narrowed Down to the Local Scale, Individual Dimension and Private Sphere

A significant number of studies have also indicated that teachers' perceptions of environmental citizenship were restricted to a much more narrowed perspective than expected [6,18,39,51]. According to Olsen et al. [39], teachers were more aware of local rather than broader socioecological system issues and felt more confident in developing learning experiences based on those issues. In a different study, Green et al. [6], who investigated qualitatively pre-service teachers' perceptions of environmental citizenship, have found that the teachers had a limited understanding of their political systems and public policy structures, which would allow them to approach environmental concerns in the collective sphere to achieve a "collective impact". Aarnio-Linnanvuori [51], who investigated teachers' perceptions of responsibility, has found that teachers framed environmental responsibility as (a) awareness, (b) relationship to nature, and (c) active citizenship. Focusing on the latter, the teachers conceptualized environmental citizenship in terms of voting (as being a responsible elector), activism (as a method of being an environmentally responsible citizen) and personal influence. However, when the teachers reflected on these actions, they mentioned that their students seldom participated in any of these. Instead, the teachers proposed several actions situated within the private sphere, such as waste management, food and consumption, transfer and energy, and highlighted that these were more feasible for their students. Finally, in a different study, Campbell and Davies [18] have noted that only a few pre-service teachers related environmental citizenship to a more general level of awareness or mainly referred to the concept in relation to personal awareness, neglecting broader dimensions of the concept in terms of the local, national or global scale.

\subsection{Characteristics}

The thematic analysis of the reviewed studies resulted in two main themes related to the characteristics of teachers' perceptions. Firstly, it appeared that teachers' perceptions are defined by different interrelated components (Theme \#3, Table 3). Secondly, according to the reviewed studies, teachers' perceptions differentiate according to teachers' educational/cultural backgrounds and personal identity (Theme \#4, Table 3). Below, we present each one of the themes, providing supporting evidence from the reviewed studies.

4.2.1. Teachers' Perceptions of Environmental Citizenship as a Multi-Dimensional Construct, Defined by Inter-Related Components

Three of the reviewed studies have investigated environmental citizenship as a multidimensional construct, defined by inter-related components $[6,39,55]$. This operationalization has allowed more in-depth insights regarding teachers' perceptions of environmental citizenship.

For instance, Olsen et al. [39] have quantitatively investigated pre-service teachers' environmental citizenship via the use of a cognitive/affective framework, defined by: (a) ecological literacy, (b) civics literacy, (c) self-efficacy, (d) values awareness, and (e) practical wisdom. According to Olsen and her colleagues, teachers' understandings of environmental citizenship were particularly decreased in terms of ecological literacy, which reflects the understanding of key ecological systems using sound ecological thinking. As Olsen et al. [39] have argued, teachers "report a gap in their understanding of social-ecological systems, which presents a barrier to developing environmental citizens, or those enacting the skills and knowledge necessary for sustainable environmental behavior" (p. 1).

Similar findings were echoed by Green et al. [6], who qualitatively investigated pre-service teachers' perceptions of environmental citizenship, using the same cogni- 
tive/affective framework as Olsen et al. [39]. According to Green et al.'s findings, the pre-service teachers showed a general understanding of key ecological systems, lacking a "place-specific understanding, particularly in regard to the social, economical, political, and cultural intricacies of their energy-yielding system and the human roles within that system" (p. 131). At the same time, the teachers indicated low levels of civics literacy, as they manifested limited understanding of public policy and civic responsibility. Lastly, according to Green et al. [6], the teachers had not really identified their personal values or what they were capable of contributing to as environmental citizens.

In a different study, Karatekin et al. [55], who have quantitatively investigated preservice teachers' environmental citizenship, as defined by (a) civic participation, (b) sustainability, (c) responsibility, as well as (d) environmental rights and justice, have found that according to teachers' scores, their general levels of environmental citizenship seemed to be moderate. However, when focusing on teachers' scores in terms of civic participation, they found that this one was particularly low in comparison with the rest of the components. Finally, Karatekin et al. [55] investigated also the various causality relations among the environmental citizenship components and reported, among others, that the most important variable directly affecting the civic participation dimension behaviors was responsibility, revealing that a higher sense of responsibility leads to higher civic participation.

4.2.2. Teachers' Perceptions of Environmental Citizenship Are Differentiated According to Their Educational/Cultural Backgrounds and Personal Identity

Five of the reviewed studies provided empirical support for the notion that teachers' perceptions of environmental citizenship are subjective, as they differentiate according to teachers' educational/cultural background and personal identity $[1,18,55,58,59]$.

Karatekin [55] has found, for instance, that the level of curiosity towards the environment as well as the frequency of participation in environmental activities positively predicted teachers' environmental citizenship. Bulut [1], who has adopted a relational research method to quantitatively investigate pre-service teachers' perceptions of environmental citizenship, has found that teachers' perceptions are differentiated according to their personal identity, in terms of gender and educational level. In particular, Bulut [1] has concluded that both the perceptions of environmental citizenship as well as the sustainable development awareness levels of the female participants were higher when compared to the male participants. In addition, he has found that both the environmental citizenship and sustainable development awareness levels of the pre-service teachers increased as the grade of the pre-service teachers increased from the freshmen to the senior level.

Contrary to these findings, Unal [59] has found that the environmental citizenship levels of the pre-service teachers did not differ significantly due to their gender, mother's educational attainment level, father's educational attainment level, membership in non-governmental organizations and membership in teachers' organizations. However, Unal [59] has identified significant differences in terms of the pre-service teachers ${ }^{\prime}$ departments and participation in social projects. More specifically, he has found that social studies teacher candidates outperformed the primary school teacher candidates, while the teacher candidates who participated in social projects outperformed their counterparts who did not. In the same vein, in a prior study, dating back to 1995, Campell and Davies [18] have also found significant differences between pre-service teachers of different disciplines. For example, as they reported, modern language pre-service teachers provided the fuller responses when defining environmental citizenship, as compared to science, mathematics, English and social studies pre-service teachers. Campell and Davies [18] explained that while this finding may simply reflect the expressive confidence of the modern language pre-service teachers, it may be also the case that this could be also attributed to the increased concern of linguists towards other cultures and places.

Finally, Paige and Cogan [58] compared the pre- and in-service perceptions of environmental citizenship at the sites Guangdong, Hong Kong and Minnesota, via investigating their top five citizen characteristics and their top five environmental problems to be addressed. According to their findings, beyond similarities, there were also striking differ- 
ences between the three populations. For instance, only the Hong Kong teachers included critical thinking on the list. Likewise, only the Minnesota teachers selected the energy resources and only Hong Kong teachers selected the uneven global resource distributions and the ozone depletion as their top environmental concerns.

\subsection{Impact}

The thematic analysis of the reviewed studies resulted in two main themes related to the impact of teachers' perceptions on their professional identity. Firstly, according to the reviewed studies, teachers' perceptions of environmental citizenship affect their teaching practices (Theme \#5, Table 3). Secondly, we found that teachers' perceptions of environmental citizenship affect other environmental constructs, which define their professional identity (Theme \#6, Table 3). Below, we present each one of the themes, providing supporting evidence from the reviewed studies.

\subsubsection{Teachers' Perceptions of Environmental Citizenship Affect Their Teaching Practices}

Four of the reviewed studies provided empirical support for the notion that teachers' perceptions of environmental citizenship affect their teaching practices [18,39,51,54].

Olsen et al. [39] have found, for instance, that while teachers attempted to integrate socioecological systems in their classrooms, they had not integrated a civic engagement component. At the same time, it was found that teachers were more aware of local socioecological system issues and ways to develop learning experiences based on those issues. Finally, when teachers were asked to report whether they believe that they can address socioecological systems through civic engagement in their classrooms, they mentioned several barriers to implementation, such as achieving standards, time, lack of congruence with subject area, energy and money.

In a different study, Aarnio-Linnanvuori [51], who investigated teachers' environmental citizenship through the lens of environmental responsibility, has found that teachers described their students' possibilities for environmental responsibility as narrower than those of adults, comprising mainly private-sphere actions. More specifically, the in-service teachers who participated in in-depth interviews expressed how small personal actions, such as recycling and switching off devices, were more feasible for the students, explaining that environmental citizenship and more impactful actions were out their students' reach.

In their study, Campbell and Davies [18] have found that there were also several pre-service teachers who could not realize the nature or the significance of awareness that should be part of education when teaching for environmental citizenship, thus rendering the environment as an area which may attract thoughtless and undefined action by their students.

Finally, Gooch et al. [54], who have analyzed environmentally focused integrated unit plans, developed and implemented by final year pre-service teachers at an Australian regional university, defined limited concepts which promoted the action competence. Based on these findings they have suggested that pre-service teachers need more preparation and support in order to be able to develop integrated unit plans that empower school students and promote critical thinking, democratic processes and action-oriented knowledge, as important skills for environmental citizenship.

\subsubsection{Teachers' Perceptions of Environmental Citizenship Affect Other Environmental Constructs Which Define Their Professional Identity}

We found only two studies providing empirical support for the notion that teachers' perceptions of environmental citizenship affect other environmental constructs which define their professional identity $[1,56]$. More specifically, Bulut [1] concluded that there was a positive correlation between environmental citizenship and sustainable development awareness levels of the pre-service teachers. In other words, as the environmental citizenship levels increased, a moderate positive improvement was observed in teachers sustainable development awareness levels. Along the same lines, Lummis et al. [56] have found in their study that the pre-service teachers' perceptions of Education for Sustainabil- 
ity and the three pillars of sustainability (environmental, economic and sociopolitical) were influenced by both teachers' environmental citizenship and political solidarity concepts as well as by the local context.

\subsection{Enhancement}

The thematic analysis of the reviewed studies resulted in two main themes related to the enhancement of environmental citizenship perceptions, due to teachers' participation in training initiatives. Firstly, it appeared that pre-service teachers' perceptions can be enhanced during teacher education (Theme \#7, Table 3). Secondly, we have found that in-service teachers' perceptions of environmental citizenship can be further improved during professional development initiatives (Theme \#8, Table 3). Table 4 provides an overview of teachers' training initiatives undertaken in the reviewed studies (i.e., training approach, target group and context of implementation, duration, indicative activities, focus on EEC). Below, we present each one of the themes, providing supporting evidence from the reviewed studies.

\subsubsection{Teachers' Perceptions of Environmental Citizenship Can Be Enhanced during Teacher Education}

Five of the reviewed studies provided empirical evidence suggesting that pre-service teachers' perceptions of environmental citizenship can be enhanced in the context of teacher education [6,53,60-62]. These studies presented and evaluated a variety of training approaches, such as project citizen [6], community-based learning [60], transformative sustainability education [62], project-based learning [53] or the use of children's ecological literature [61].

Abd-El-Aal and Steele [60] have reported, for instance, that pre-service teachers had the opportunity to take part in community-based learning which allowed them to reveal environmental problems in their local communities (e.g., water pollution, pesticides, garbage, wasting of environmental resources), while joining forces with the residents to undertake either individual actions situated at the private sphere (e.g., water conservation, use of alternative pesticides, garbage pick-up) or collective actions situated in the public sphere (e.g., sign a complaint to local councils, distribution of informative flyers, organization of symposiums, preparation of posters, purchase of bins). In a different study, Chaya and Ali [53] reported on the participation of pre-service teachers in a problem-based project, which allowed them to identify various environmental problems in their local communities, to collect relevant information and propose solutions. Likewise, Green et al. [6] described pre-service teachers' involvement in Project Citizen as a "critical place-based action-oriented approach for integrating environmental citizenship in teacher education" (p. 122). According to this approach, the pre-service teachers identified a local public policy problem (i.e., energy conservation on campus), gathered public opinions about this problem, took an active role within the public sphere to collectively devise an educational policy that promoted energy-saving behaviors within the university campus and, finally, they presented their policy to university decision-makers.

In a different study, Gal and Gan [62] reported that pre-service teachers had the opportunity to take part in a series of field trips, which were grounded in the Transformative Sustainability Approach. Each field trip allowed teachers to obtain rich insights regarding the complexity of three different social-ecological systems, introduced major environmental issues threating their sustainability, fostered critical thinking, allowed a deeper understanding of the socioecological systems and motivated teachers to undertake socialenvironmental actions either within the public or private sphere. Finally, Bradberry [61] reported on how children's ecological literature was used in order to communicate across several environmental challenges as well as to provoke the pre-service teachers' critical thinking regarding the interdependence of all of the elements of any fragile environment and the need to protect these, as well as what needs to be done in order to secure an ecologically sustainable future for our Earth. 
Table 4. Overview and characteristics of teachers' training initiatives.

\begin{tabular}{|c|c|c|c|c|c|c|}
\hline$\#$ & Author(s)/Year & Training Approach & $\begin{array}{l}\text { Target Group \& Context } \\
\text { of Implementation }\end{array}$ & Duration & Indicative Activities & $\begin{array}{c}\text { Focus on EEC (Outputs, } \\
\text { Dimensions, Spheres, Scales) }\end{array}$ \\
\hline 1 & $\begin{array}{l}\text { Abd-El-Aal \& } \\
\text { Steele, } 2013\end{array}$ & $\begin{array}{l}\text { Community-based } \\
\text { learning: According to this } \\
\text { approach, the pre-service } \\
\text { teachers were asked to } \\
\text { investigate and take action } \\
\text { on environmental issues in } \\
\text { their communities. This } \\
\text { approach allowed them to } \\
\text { take leadership roles in local } \\
\text { environmental issues, rather } \\
\text { than simply focusing on } \\
\text { general knowledge about } \\
\text { the environment. }\end{array}$ & $\begin{array}{l}38 \text { pre-service teachers } \\
\text { (Teacher education: } \\
\text { Environmental } \\
\text { Education course) }\end{array}$ & $\begin{array}{l}\text { A semester- } \\
\text { long course } \\
\text { (the exact } \\
\text { duration is } \\
\text { not specified) }\end{array}$ & $\begin{array}{l}\text { - Identification of environmental } \\
\text { problems in teachers' } \\
\text { local communities } \\
\text { - Fieldwork and semi-structured } \\
\text { interviews with } \\
\text { community members } \\
\text { Development of solutions in } \\
\text { collaboration with the } \\
\text { community members } \\
\text { Preparation of final reports with } \\
\text { the fieldwork artifacts (e.g., videos } \\
\text { and photographs) }\end{array}$ & $\begin{array}{l}\text { - } \\
\text { takents of change: Investigating and } \\
\text { issues in local communities } \\
\text { - } \quad \text { Dimensions: Individual and } \\
\text { collective actions } \\
\text { - Spheres: Private and public sphere } \\
\text { actions } \\
\text { - } \quad \text { Scales: Local-scale actions } \\
\text { Outputs: } \\
-\quad \text { Solving current } \\
\text { environmental problems } \\
-\quad \text { Achieving critical and active } \\
\text { engagement and civic participation }\end{array}$ \\
\hline 2 & $\begin{array}{l}\text { Avriel-Avni \& } \\
\text { Gan, } 2019\end{array}$ & $\begin{array}{l}\text { Conceptual mapping: } \\
\text { According to this approach, } \\
\text { in-service teachers created } \\
\text { three concept maps } \\
\text { throughout the course, to } \\
\text { map their field of action. } \\
\text { Through mapping, the } \\
\text { in-service teachers identified } \\
\text { their role as environmental } \\
\text { citizens within the } \\
\text { socioenvironmental system } \\
\text { and identified possible ways } \\
\text { to influence it. }\end{array}$ & $\begin{array}{l}24 \text { in-service teachers } \\
\text { (Teacher education: } \\
\text { Environmental } \\
\text { Education Master's } \\
\text { course) }\end{array}$ & $\begin{array}{l}\text { Two- } \\
\text { semester- } \\
\text { long course } \\
\text { (the exact } \\
\text { duration is } \\
\text { not specified) }\end{array}$ & $\begin{array}{l}\text { - Identification of environmental } \\
\text { problems causing discomfort } \\
\text { - Group mapping to map the } \\
\text { processes that preserve the } \\
\text { undesirable reality and processes } \\
\text { that can bring change } \\
\text { - Studying remote and unfamiliar } \\
\text { environmental cases } \\
\text { - Creation of personal maps } \\
\text { indicating socioenvironmental } \\
\text { problems as well as their driving } \\
\text { and preserving forces } \\
\text { Joint analysis of field maps and } \\
\text { individual feedback on mappings }\end{array}$ & $\begin{array}{l}\text { - } \\
\text { mapents of change: Investigating and } \\
\text { mapping field of action in relation to a } \\
\text { local environmental problem } \\
\text { (e.g., waste management) } \\
\text { Dimensions: Individual and } \\
\text { collective actions } \\
\text { - Spheres: Private and public } \\
\text { sphere actions } \\
\text { - } \quad \text { Scales: Local-scale actions } \\
\text { Outputs: } \\
-\quad \text { Solving current } \\
\quad \text { environmental problems } \\
\text { - Identifying structural causes of } \\
\text { environmental problems } \\
\text { - Achieving critical and active } \\
\text { engagement and civic participation }\end{array}$ \\
\hline
\end{tabular}


Table 4. Cont.

\begin{tabular}{|c|c|c|c|c|c|c|}
\hline$\#$ & Author(s)/Year & Training Approach & $\begin{array}{l}\text { Target Group \& Context } \\
\text { of Implementation }\end{array}$ & Duration & Indicative Activities & $\begin{array}{c}\text { Focus on EEC (Outputs, } \\
\text { Dimensions, Spheres, Scales) }\end{array}$ \\
\hline 3 & Bradberry, 2013 & $\begin{array}{l}\text { Children's literature: } \\
\text { Children's literature with } \\
\text { strong ecological themes was } \\
\text { selected, analyzed and } \\
\text { thoroughly discussed with } \\
\text { pre-service teachers as part of } \\
\text { this approach. The aim of this } \\
\text { approach was to support } \\
\text { pre-service teachers in } \\
\text { developing children's } \\
\text { environmental citizenship for } \\
\text { achieving an ecologically } \\
\text { sustainable future. }\end{array}$ & $\begin{array}{l}140 \text { pre-service teachers } \\
\text { (Teacher education: } \\
\text { Environmental } \\
\text { Education course) }\end{array}$ & $\begin{array}{l}\text { A semester- } \\
\text { long course of } \\
12 \text { weeks } \\
\text { (the exact } \\
\text { duration is } \\
\text { not specified) }\end{array}$ & $\begin{array}{l}\text { - Character focus activities to explore } \\
\text { the complexity of } \\
\text { socioenvironmental issues } \\
\text { - Use of inferential reading and } \\
\text { critical thinking } \\
\text { questioning strategies } \\
\text { Deconstruction of the text's } \\
\text { visual elements } \\
\text { Problem-based learning activities } \\
\text { using the narrative text as a catalyst }\end{array}$ & $\begin{array}{l}\text { - Agents of change: Reflecting on } \\
\text { various role models, characters and } \\
\text { potential civic actions in the context } \\
\text { of children's literature and } \\
\text { ecopedagogy } \\
\text { Outputs: } \\
-\quad \text { Achieving critical and active } \\
\quad \text { engagement and } \\
\quad \text { civic participation } \\
-\quad \text { Achieving sustainability } \\
-\quad \text { Healthy relationship } \\
\quad \text { with nature }\end{array}$ \\
\hline 4 & Chaya \& Ali, 2016 & $\begin{array}{l}\text { Project-based learning (PBL): } \\
\text { PBL required teachers to } \\
\text { investigate environmental } \\
\text { problems in their communities. } \\
\text { It provided opportunities to } \\
\text { actively explore and address } \\
\text { environmental challenges } \\
\text { while developing skills in } \\
\text { communication and } \\
\text { teamwork, research, data } \\
\text { collection and analysis, } \\
\text { community engagement } \\
\text { and reflection. }\end{array}$ & $\begin{array}{l}222 \text { pre-service teachers } \\
\text { (Teacher education: } \\
\text { Environmental } \\
\text { Education course) }\end{array}$ & $\begin{array}{l}\text { One semester } \\
\text { (the exact } \\
\text { duration is } \\
\text { not specified) }\end{array}$ & 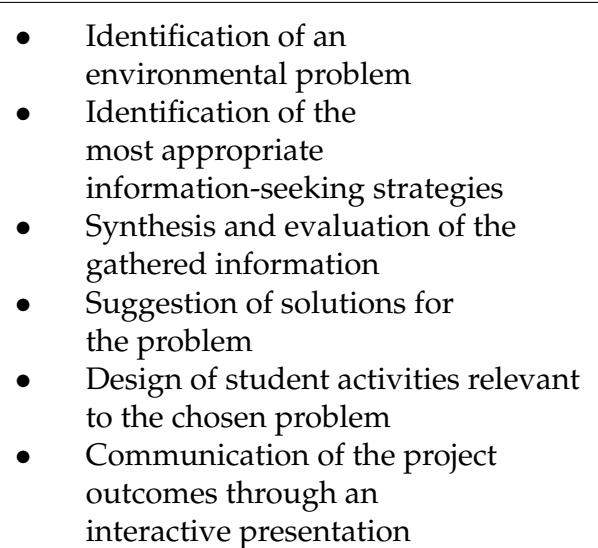 & $\begin{array}{l}\text { - Agents of change: Investigating } \\
\text { and addressing environmental } \\
\text { problems in the context of } \\
\text { PBL projects } \\
\text { - } \quad \text { Dimensions: Not specified } \\
\text { - Spheres: Not specified } \\
\text { - Scales: Local-scale actions } \\
\text { - Outputs: } \\
\text { - Solving current } \\
\text { environmental problems } \\
\text { - Achieving critical and active } \\
\text { engagement and } \\
\text { civic participation }\end{array}$ \\
\hline
\end{tabular}


Table 4. Cont.

\begin{tabular}{|c|c|c|c|c|c|c|}
\hline$\#$ & Author(s)/Year & Training Approach & $\begin{array}{l}\text { Target Group \& Context } \\
\text { of Implementation }\end{array}$ & Duration & Indicative Activities & $\begin{array}{c}\text { Focus on EEC (Outputs, } \\
\text { Dimensions, Spheres, Scales) }\end{array}$ \\
\hline 5 & Gal \& Gan, 2020 & $\begin{array}{l}\text { Transformative Sustainability } \\
\text { Education (TSE): TSE served as } \\
\text { an effective approach in creating } \\
\text { behavioral transformation } \\
\text { related to environmental } \\
\text { problems. In this study, TSE was } \\
\text { employed in context of three } \\
\text { field trips; each field trip } \\
\text { provided to the teachers insights } \\
\text { regarding the complexity of the } \\
\text { social-ecological systems in } \\
\text { Israel and introduced major } \\
\text { environmental issues at local, } \\
\text { regional and } \\
\text { international levels. }\end{array}$ & $\begin{array}{l}20 \text { pre-service teachers } \\
\text { (Teacher education: } \\
\text { Environmental } \\
\text { Education course) }\end{array}$ & $\begin{array}{l}\text { One semester } \\
\text { (the exact } \\
\text { duration is } \\
\text { not specified) }\end{array}$ & $\begin{array}{l}\text { - Jigsaw activities, where each } \\
\text { pre-service teacher studied one } \\
\text { part of a topic and then teachers } \\
\text { reconvened to bring all parts of } \\
\text { the information together } \\
\text { Peer learning during which the } \\
\text { pre-service teachers shared their } \\
\text { insights from the field trips } \\
\text { Drawings reflecting the } \\
\text { social-ecological systems } \\
\text { according to pre-service teachers' } \\
\text { understanding } \\
\text { Personal and group reflections } \\
\text { for each field trip }\end{array}$ & $\begin{array}{l}\text { - Agents of change: Investigating } \\
\text { various socioecological systems and } \\
\text { addressing environmental challenges in } \\
\text { the context of field trips } \\
\text { - Dimensions: Not specified } \\
\text { - } \quad \text { Spheres: Private and public actions } \\
\text { - } \quad \text { Scales: Local-scale actions } \\
\text { Outputs: } \\
-\quad \text { Solving current } \\
-\quad \text { environmental problems } \\
-\quad \text { Achieving sustainability } \\
\text { - engagement and civic participation } \\
\text { - Healthy relationship with nature }\end{array}$ \\
\hline 6 & Green et al., 2016 & $\begin{array}{l}\text { Project citizen: A critical } \\
\text { place-based action-oriented } \\
\text { approach for the integration of } \\
\text { environmental citizenship in } \\
\text { teacher education. It allowed } \\
\text { teachers to address social, } \\
\text { cultural, economical and } \\
\text { political complexities in their } \\
\text { local communities, while also } \\
\text { empowering them to explore } \\
\text { how their personal experiences } \\
\text { and background shape their } \\
\text { engagement in } \\
\text { democratic processes. }\end{array}$ & $\begin{array}{l}7 \text { pre-service teachers } \\
\text { (undergraduate } \\
\text { students) (Teacher } \\
\text { education: } \\
\text { Environmental } \\
\text { Education course) }\end{array}$ & $\begin{array}{l}\text { One semester } \\
\text { (the exact } \\
\text { duration is } \\
\text { not specified) }\end{array}$ & $\begin{array}{l}\text { - Identification of a public policy } \\
\text { problem in local communities } \\
\text { Collection of information about } \\
\text { the various dimensions of } \\
\text { the problem } \\
\text { Development of a portfolio } \\
\text { which includes an explanation } \\
\text { of the problem, alternative } \\
\text { approaches and a course } \\
\text { of action } \\
\text { Sharing of the portfolio with } \\
\text { decision-makers and } \\
\text { interested stakeholders } \\
\text { Reflection on the } \\
\text { learning experience }\end{array}$ & $\begin{array}{l}\text { - Agents of change: Identifying a local } \\
\text { public policy problem and taking an } \\
\text { active role within the public sphere to } \\
\text { collectively devise a policy to address } \\
\text { this problem } \\
\text { - } \\
\text { - } \quad \text { Sphensions: Collective actions } \\
\text { - } \quad \text { Scales: Local-scale actions } \\
\text { - } \quad \text { Outputs: } \\
\text { - Solving current } \\
\text { - } \text { Achironmental problems sustainability } \\
-\quad \text { Achieving critical and active } \\
\text { engagement and civic participation }\end{array}$ \\
\hline
\end{tabular}


Table 4. Cont.

\begin{tabular}{|c|c|c|c|c|c|c|}
\hline$\#$ & Author(s)/Year & Training Approach & $\begin{array}{l}\text { Target Group \& Context } \\
\text { of Implementation }\end{array}$ & Duration & Indicative Activities & $\begin{array}{c}\text { Focus on EEC (Outputs, } \\
\text { Dimensions, Spheres, Scales) }\end{array}$ \\
\hline 7 & Olsen et al., 2020 & $\begin{array}{l}\text { Adventure Learning (AL) } \\
\text { approach: A hybrid approach } \\
\text { which combined an online } \\
\text { collaborative learning environment } \\
\text { with adventure-based authentic } \\
\text { learning experiences for the } \\
\text { exploration of real-world issues } \\
\text { connected to particular places. This } \\
\text { approach was addressed to both } \\
\text { local (face-to-face) and distance } \\
\text { (online) participants (teachers) and } \\
\text { was grounded in } \\
\text { experiential and inquiry-based } \\
\text { learning theory. }\end{array}$ & $\begin{array}{l}94 \text { in-service teachers in } \\
\text { both primary and } \\
\text { secondary education } \\
\text { (Professional } \\
\text { Development program) }\end{array}$ & $\begin{array}{l}\text { - Online } \\
\text { participation: } \\
\text { Approx. } 20 \mathrm{~h} \\
\text { - } \quad \text { In-person } \\
\text { workshops: } \\
\text { Approx. } 40 \mathrm{~h}\end{array}$ & $\begin{array}{l}\text { - In-person workshops about } \\
\text { the exploration of local } \\
\text { socioecological systems in } \\
\text { teachers' communities } \\
\text { Interaction with regional } \\
\text { experts, researchers } \\
\text { and stakeholders } \\
\text { Investigation of self-selected } \\
\text { socioecological topics in } \\
\text { small groups } \\
\text { Reflections with off-site } \\
\text { participants in the } \\
\text { online environment }\end{array}$ & $\begin{array}{ll}\text { - } & \text { Agents of change: Investigating } \\
& \text { real-world issues connected to } \\
\text { - } & \text { particular places } \\
\text { - } & \text { Sphensions: Collective actions } \\
\text { - } & \text { Scales: Local-scale actions } \\
\text { - } & \text { Outputs: } \\
-\quad \text { Solving current } \\
\quad \text { environmental problems } \\
-\quad \text { Achieving critical and } \\
\text { active engagement and } \\
\text { civic participation }\end{array}$ \\
\hline 8 & $\begin{array}{l}\text { Spektor-Levy \& } \\
\text { Abramovich, } 2020\end{array}$ & $\begin{array}{l}\text { Environmental Leadership } \\
\text { Professional Development } \\
\text { (ELPD): This approach was } \\
\text { structured around the teachers' } \\
\text { effort to plan an innovative venture } \\
\text { related to environmental and } \\
\text { sustainability issues and combined } \\
\text { five main characteristics, as follows: } \\
\text { - Pro-social and } \\
\text { environmental activism } \\
\text { - } \quad \text { Project-based learning } \\
\text { Empowerment } \\
\text { and self-efficacy } \\
\text { Greater knowledge-more } \\
\text { courage to dare/act } \\
\text { Place-based learning }\end{array}$ & $\begin{array}{l}46 \text { in-service teachers at } \\
\text { pre-school education } \\
\text { (Professional } \\
\text { Development program) }\end{array}$ & $\begin{array}{l}120 \text { h: } 15 \\
\text { face-to-face } \\
\text { sessions lasting } \\
\text { eight hours each }\end{array}$ & $\begin{array}{ll}\text { - } & \text { Meetings and workshops for } \\
\text { knowledge enrichment } \\
\text { - } \quad \begin{array}{l}\text { Project-based } \\
\text { learning activities } \\
\text { - }\end{array} \text { Surveying and identification } \\
\text { of local socioenvironmen- } \\
\text { tal problems } \\
\text { - Online and offline group } \\
\text { discussions and } \\
\text { collaborative } \\
\text { learning activities } \\
\text { Experiential and reflective } \\
\text { learning activities. }\end{array}$ & $\begin{array}{l}\text { - Agents of change: Planning an } \\
\text { innovative venture related to } \\
\text { environmental and } \\
\text { sustainability issues } \\
\text { Outputs: } \\
-\quad \text { Achieving sustainability } \\
-\quad \text { Achieving critical and } \\
\text { active engagement and } \\
\text { civic participation }\end{array}$ \\
\hline
\end{tabular}


Overall, despite their differences, these training approaches were characterized by various learning activities, which contributed to several aspects of the Education for Environmental Citizenship (EEC). In most of these studies, the pre-service teachers had the opportunity to realize that environmental citizenship is manifested via undertaking various actions at the local level, either collectively or individually, within the private or public sphere, to address current environmental problems [6,53,60,62]. Importantly, these studies put forward some of the main outputs, which the Education for Environmental Citizenship (EEC) is striving for, such as: (a) solving current environmental problems [6,53,60,62], (b) achieving critical and active engagement and civic participation [6,53,60-62], (c) achieving sustainability $[61,62]$ as well as (d) developing a healthy relationship with nature $[61,62]$.

\subsubsection{Teachers' Perceptions Can Be Enhanced during Professional Development Initiatives}

Three of the reviewed studies provided empirical evidence suggesting that in-service teachers' perceptions can be further improved during professional development programs [39,52,57]. More specifically, Olsen et al. [39] presented a professional development program grounded in the Adventure Learning (AL) approach, which combined an online collaborative learning environment with adventure-based authentic learning experiences for the exploration of real-world issues connected to particular places. As part of the program, the in-service teachers had the opportunity to enhance their environmental citizenship perceptions by participating in a variety of activities, such as in-person workshops about the exploration of local socioecological systems in teachers' communities, interaction with regional experts and stakeholders, investigation of self-selected socioecological topics in small groups as well as reflections with off-site participants in the online environment.

In a different study, Spektor-Levy and Abramovich [57] reported on the positive impact of the environmental leadership professional development program, during which the participating in-service teachers were asked to plan an innovative venture related to environmental and sustainability issues. Finally, Avriel-Avni and Gan [52] presented conceptual mapping as an approach, according to which the in-service teachers created three concept maps throughout a Master's course on Environmental Education, to map their field of action regarding waste management, as a socioenvironmental problem. Teachers' mapping provided a useful lens to the tutors of the course to support the in-service teachers to identify their role as environmental citizens within the socioecological system, to conceptualize various collective or individual environmental actions at the private or public sphere (e.g., placement of recycling bins, city campaigns, self-recycling, composting) as well as to explore the driving and preserving structural forces underlying the problem.

Overall, the aforementioned professional development interventions were characterized by various learning activities, which contributed to several aspects of the Education for Environmental Citizenship (EEC). As part of these interventions, a common element was that in-service teachers were asked to conceptualize solutions for local environmental problems that they were asked to investigate and reflect on [39,52,57]. These professional development programs fostered also some of the main outputs, which the Education for Environmental Citizenship (EEC) is aiming at, such as: (a) solving current environmental problems [39,52,57], (b) identifying the structural causes of environmental problems [48], (c) achieving critical and active engagement and civic participation [39,52,57], (d) achieving sustainability [57].

\section{Discussion}

The goal of this review study is to further extend the field's understanding of teachers' perceptions of environmental citizenship via a systematic synthesis of the literature. To achieve this goal, we reviewed and synthesized the findings of quantitative and qualitative investigations on the topic, published in peer-reviewed journals from 1995 to 2020. Our main findings are discussed below for each one of the research questions guiding this review study. 


\subsection{Teachers' Conceptualization of Environmental Citizenship}

Our first research question focused on the way teachers conceive environmental citizenship. The synthesis of the reviewed research has indicated that teachers' perceptions of environmental citizenship are generally naïve or superficial. On one hand, quantitative studies provided empirical evidence supporting the notion that teacher levels of environmental citizenship were moderate to low $[39,55]$. On the other hand, qualitative studies showed that many teachers could not provide a clear definition of what environmental citizenship really is $[6,56]$. Focusing on teachers' perceptions of what environmental citizenship entails, teachers framed environmental citizenship as a potential venue to address issues on local ecosystems and via an individual rather than a collective dimension. At the same time, they related environmental citizenship only with simplistic, daily, personal actions on behalf of their students. In this way, environmental citizenship mostly appeared as the "low-hanging fruit" of individual personal behaviors-recycling, energy saving and home insulation [63]. Indeed, Environmental Education has often been criticized for simply promoting insignificant individual behaviors $[5,64]$. However, as was posed by Aarnio-Linnanvuori [51], if teachers cannot imagine significant active roles as well as more collective and influential actions towards addressing global environmental challenges, how can they support their students' growth in environmental citizenship?

Overall, the reviewed studies suggest that teachers had limited exposure to and understanding of environmental citizenship. Therefore, teachers should be given the opportunity to become familiar with the concept of environmental citizenship, as was clarified through interdisciplinary interactions between experts [65]. If we hope to educate individuals not only to act pro-environmentally, but to understand the urgency of environmental issues and to integrate pro-environmental actions into the core of their political participation and citizenship expressions, all aspects that comprise environmental citizenship need to be tackled specifically, systematically and precisely within educational dimensions. Of course, teachers are likely to build their conceptual understanding of environmental citizenship on the foundation of their own subject traditions [66]. Nevertheless, earlier studies have shown that if teachers have a holistic understanding of concepts such as environmental citizenship, they will use a broader approach to teaching and learning, while a narrowed understanding is often associated with narrow approaches to teaching [67].

\subsection{Characteristics of Teachers' Perceptions of Environmental Citizenship}

Our second research question focused on the characteristics of teachers' perceptions of environmental citizenship and our findings shed light on the complex nature of these perceptions. The synthesis of the reviewed studies provided empirical support for the notion that teachers' perceptions of environmental citizenship can be characterized as highly subjective, as they are affected by teachers' educational and cultural backgrounds as well as by their personal identity (e.g., gender, curiosity towards the environment, participation in environmental activities). In a way, this is not a novel finding, as prior literature has reported how teachers' perceptions of various topics vary due to their personal identity [68-71]. However, as teachers' environmental citizenship perceptions are still an emerging topic, further research should be undertaken to specify teachers' remarkable personal identity differences as well as their exact contribution to the formation of their environmental citizenship perceptions. This need is further warranted, considering not only the limited number of empirical studies investigating the role that teachers' personal identity plays on their perceptions of environmental citizenship, but also on their contradictive findings regarding the impact of these differences (see, for instance, how the role of teacher gender differences is reported in the studies of Bulut [1] and Unal [59]).

On the other hand, a subgroup of the reviewed empirical studies $[6,39,55]$ characterized teachers' perceptions of environmental citizenship as multifaceted constructs, comprising various subcomponents (i.e., ecological literacy, civic literacy, practical wisdom, self-efficacy, values awareness, civic participation, sustainability, responsibility, environmental right and justice). This multidimensional characterization revealed a variation 
in teachers' level of understanding across the evaluated subcomponents, with the teachers reporting the greatest gap in their understanding of "ecological literacy", "practical wisdom" and "participation". "Ecological literacy" reflects teachers' understanding of key ecological systems using sound ecological thinking, while "practical wisdom" and "participation" reflect action-oriented components entailing skills for decision-making and acting with respect to the environment [4]. These findings are aligned with prior literature reporting that environmental behaviors which require active participation for the solution of socioecological problems are poorly evaluated $[17,72,73]$, and as such, training initiatives should be more targeted towards addressing these less evaluated dimensions.

\subsection{Impact of Teachers' Environmental Citizenship Perceptions on Their Professional Identity}

Our third research question sought to understand the impact of teachers' environmental citizenship perceptions on their professional identity. According to the synthesis of the reviewed studies, we have found that teachers' perceptions of environmental citizenship are positively correlated with and affect teachers' sustainable development awareness levels as well as their perceptions for Education for Sustainability [1,56]. This finding is significant given the worldwide efforts to foster education for sustainability by UNESCO as well as the main goals and targets which were set by the United Nations towards this direction, to be achieved by $2030[74,75]$.

Importantly, the synthesis of the reviewed studies has indicated that the way teachers perceive environmental citizenship primarily affects their current teaching practices as well as the ways they intend to foster their students' environmental citizenship. In short, the teachers' reported practices for promoting students' environmental citizenship remained limited to the use of local socioenvironmental issues and individual actions at the private sphere. As also appeared, teachers had great difficulty in integrating action-oriented knowledge and authentic civic engagement activities as part of their lessons. These findings are not surprising, considering the way teachers perceived environmental citizenship and their limited understanding around the concept. In general, how teachers perceive central educational concepts in the curriculum inevitably affects their interpretation and implementation [76]. In addition, teachers make educational decisions and interpret and deliver the educational content based on their environmental perceptions [51]. Teachers' perceptions may limit their willingness and effectiveness to teach pro-environmental content included in the curriculum [77]. This provides a plausible explanation regarding our findings about the discouraging relationship of teachers' environmental citizenship perceptions with their teaching practices. This situation is worsened due to the fact that environmental citizenship is not an explicit component of a particular subject's curriculum, so far, which makes it more challenging for teachers to address it in their teaching.

\subsection{Enhancement of Teachers' Environmental Citizenship Perceptions}

Our fourth research question asked whether and how teachers' environmental citizenship perceptions can be enhanced. The synthesis of the reviewed studies provided empirical support suggesting that pre-service teachers' perceptions of environmental citizenship can be enhanced in the context of teacher education courses [6,53,60-62], while in-service teachers' perceptions can be further improved in the context of professional development programs $[39,52,57]$. This subset of empirical studies is of critical importance given that, while supporting teachers in enacting environmental citizenship is now a prescient concern [20], opportunities for teacher training delivering environmental citizenship education are limited and its effectiveness remains understudied [39]. The reviewed studies provided a range of training initiatives for in-service and pre-service teachers, which tapped into and highlighted various aspects of the Education for Environmental Citizenship (EEC), via supporting teachers in becoming and acting as agents for change. More specifically, in most of the training initiatives, the teachers had the opportunity to undertake or to suggest individual or collective civic actions either at the private or the public sphere, which could contribute to the mitigation of current socioenvironmental issues. Despite their range, these 
actions were restricted at the local scale; none of the actions were expanded at the national or global scale. The attention given by the reviewed training initiatives to place-based learning presented the opportunity to teachers to be involved in local-scale environmental problems; however, equal attention has not been given to national- and global-scale environmental problems. These training initiatives fostered also to a great degree some of the main outputs, which the Education for Environmental Citizenship (EEC) is aiming at, such as solving current environmental problems, or achieving critical and active engagement and civic participation, while also promoting to a lesser degree outputs such as identifying the structural causes of environmental problems, achieving sustainability or developing a healthy relationship with nature. However, according to the European Network for Environmental Citizenship (ENEC) [34], the EEC is also characterized by several other outputs, such as: (a) preventing environmental problems, (b) practicing environmental rights and duties, and (c) promoting inter- and intra-generational justice, which were not promoted at all by the reviewed training initiatives and the educational approaches adopted. These findings coincide with Hadjichambis and Paraskeva-Hadjichambi [20], who proposed that none of the existing educational approaches alone can promote the scope and aims of the EEC and, therefore, a more integrated and holistic pedagogical approach is needed.

\section{Limitations}

Even though the findings of this review study may help flesh out a more comprehensive picture regarding teachers' perceptions of environmental citizenship, some limitations of this work are also important to note. First, a critical issue is the lack of consensus on an operational definition or a model of environmental citizenship in the reviewed studies. Environmental citizenship was often labelled as "green", "ecological" "sustainability" or even "global" and "active" citizenship, signifying also a variation in research conceptions of environmental citizenship and what it entails. This variation in research conceptions makes it almost impossible to compare findings meta-analytically, while in other cases, the differences are not distinguishable [2]. Secondly, the fact that our review included only 16 empirical studies could be perceived as another limitation. This is attributed to the fact that the empirical research on the topic is still emerging. Yet, we proceeded in a well-crafted and analytical synthesis of the available empirical research, with the aim of providing useful directions for researchers in the field.

\section{Educational Implications and Future Directions}

The goal of this review study was to synthesize the results of empirical research on teachers' perceptions of environmental citizenship. Based on our findings, we propose several areas for future research.

First, the field seems to be still in an exploratory phase. This is not only justified by the limited number of retrieved empirical studies on the topic or by the year of their publication, but also from the research designs they have followed. Most of the reviewed papers have presented, for instance, qualitative case studies in an effort to explore in more depth teachers' perceptions of environmental citizenship. Future studies should therefore seek to validate and replicate prior findings across larger teacher groups and different settings.

Secondly, while the reviewed literature provided some initial insights into how teachers' perceptions seem to vary according to teachers' educational/cultural background and personal identity (e.g., gender, levels of environmental curiosity, participation in environmental projects), more research work is warranted towards this direction. Additional personal identity aspects of interest could include, for instance, teachers' environmental background and content knowledge, professional expertise or their personal levels of environmental activism. At the same time, the reviewed research provided no insights into how teachers' perceptions of environmental citizenship vary by social context and setting. For instance, nothing is known about how teachers' perceptions of environmental citizenship vary across formal or informal educational settings (i.e., teachers' perceptions employed at 
formal schools versus teachers' perceptions employed at Environmental Education centers), or across urban, suburban and rural school settings. In addition, nothing is yet known about the social context in different countries, which may affect teachers' perceptions of environmental citizenship. Such research questions could be investigated with the use of experimental research designs, employing control or comparison groups, which were almost non-existent in the reviewed studies.

Third, future empirical studies could be more targeted towards investigating and addressing teachers' perceptions, in respect to the particular weaknesses and gaps identified in this reviewed study. More specifically, it has been found that teachers' perceptions are narrowed down to the local scale, individual dimension and private sphere. Put simply, according to the teachers, environmental citizenship was operationalized as a vehicle to address local environmental challenges via an individualistic perspective, neglecting global environmental problems as well as the significance of collective environmental actions. The evaluation of environmental citizenship perceptions as multidimensional constructs also revealed a gap in teachers' understanding of socioecological systems and action-oriented practices. Taking into account these findings, future training initiatives should include more focused activities in order to empower teachers' understanding of these particular aspects.

Fourth, taking into account that none of the existing educational approaches alone can promote the scope and aims of the EEC, existing and new educational approaches should be further investigated in the context of training initiatives for in-service and pre-service teachers. One potential direction would be the design of training initiatives which combine a variety of educational approaches (e.g., community-service learning, field mapping, and children's literature/ecopedagogy). On the other hand, a more viable approach would be the design and implementation of educational approaches explicitly structured around the model of EEC per se, taking into account its scope and aims. In their latest work, Hadjichambis and Paraskeva-Hadjichambi [20] have developed, for instance, the EEC pedagogical approach, which comprises six stages, as follows: (a) Inquiry, (b) Planning actions, (c) Critical and active engagement and civic participation, (d) Networking and sharing in scales (local, national, global), (e) Sustain environmental and social change, and (f) Evaluation and reflection. According to Hadjichambis and Paraskeva-Hadjichambi [20], the value of this approach is concentrated on the notion that it is placed at the heart of environmental citizenship and it was structured around the model of the Education for Environmental Citizenship (EEC), as this was developed by the European Network for Environmental Citizenship (ENEC) [34]. Despite these arguments, the proposed pedagogical approach has to be tested with pre-service and in-service teachers in the context of future teachers' training initiatives duly designed for this purpose.

Finally, there is also a need for longitudinal research studies and trajectories, reporting how teachers' perceptions on environmental citizenship evolve from their pre-service training into their in-service careers. At a smaller timescale, longitudinal studies could also be used to investigate the short- and long-term impact of professional development programs. Focusing on the latter, future empirical studies should be undertaken investigating the impact of professional development and teacher education initiatives not only on teachers' perceptions on environmental citizenship but also on how these perceptions are reflected on teaching practices, within the school classrooms, in the framework of EEC.

Author Contributions: Conceptualization, Y.G.; methodology, Y.G., A.C.H. and D.H.; formal analysis, Y.G., A.C.H. and D.H.; investigation, Y.G.; writing—original draft preparation, Y.G.; writing—review and editing, A.C.H. and D.H.; visualization, Y.G.; project administration, Y.G. All authors have read and agreed to the published version of the manuscript.

Funding: This research received no external funding.

Institutional Review Board Statement: Not applicable.

Informed Consent Statement: Not applicable. 
Data Availability Statement: No new data were created or analyzed in this study. Data sharing is not applicable to this article.

Acknowledgments: This study is partly inspired by Cost Action ENEC—European Network for Environmental Citizenship (CA16229) supported by COST (European Cooperation in Science and Technology).

Conflicts of Interest: The authors declare no conflict of interest.

\section{References}

1. Bulut, B. Correlation between global citizenship and sustainable development awareness levels of pre-service teachers. Int. Online J. Educ. Sci. 2019, 11. [CrossRef]

2. Hadjichambis, A.C.; Reis, P. Introduction to the Conceptualisation of Environmental Citizenship for Twenty-First-Century Education. In Conceptualizing Environmental Citizenship for 21st Century Education; Springer: Cham, Switzerland, 2020; pp. 1-14.

3. UNESCO-UNEP. Intergovernmental Conference on Environmental Education, Organized by UNESCO in Co-Operation with UNEP; Final Report; UNIPUB: New York, NY, USA, 1977; Volume Connect 3.

4. Berkowitz, A.R.; Ford, M.E.; Brewer, C. A framework for integrating ecological literacy, civics literacy, and environmental citizenship in environmental education. Environ. Educ. Advocacy Chang. Perspect. Ecol. Educ. 2005, 227-266. [CrossRef]

5. Chawla, L.; Cushing, D.F. Education for strategic environmental behavior. Environ. Educ. Res. 2007, 13, 437-452. [CrossRef]

6. Green, C.; Medina-Jerez, W.; Bryant, C. Cultivating environmental citizenship in teacher education. Teach. Educ. 2016, 27, 117-135. [CrossRef]

7. Schusler, T.M.; Krasny, M.E.; Peters, S.J.; Decker, D.J. Developing citizens and communities through youth environmental action. Environ. Educ. Res. 2009, 15, 111-127. [CrossRef]

8. Short, P. Responsible environmental action: Its role and status in environmental education and environmental quality. J. Environ. Educ. 2009, 41, 7-21. [CrossRef]

9. Dobson, A. Environmental citizenship: Towards sustainable development. Sustain. Dev. 2007, 15, 276-285. [CrossRef]

10. Dono, J.; Webb, J.; Richardson, B. The relationship between environmental activism, pro-environmental behaviour and social identity. J. Environ. Psychol. 2010, 30, 178-186. [CrossRef]

11. Gunningham, N.; Kagan, R.A.; Thornton, D. Social license and environmental protection: Why businesses go beyond compliance. Corp. Environ. Responsib. 2017, 29, 485-519. [CrossRef]

12. Dietz, T.; Stern, P.C. New Tools for Environmental Protection. New Tools Environ. Prot. 2002, 3. [CrossRef]

13. Činčera, J.; Romero-Ariza, M.; Zabic, M.; Kalaitzidaki, M.; del Consuelo Díez Bedmar, M. Environmental Citizenship in Primary Formal Education. In Conceptualizing Environmental Citizenship for 21st Century Education; Springer: Cham, Switzerland, 2020; pp. $163-177$.

14. Schachter, R.E. An Analytic Study of the Professional Development Research in Early Childhood Education. Early Educ. Dev. 2015, 26, 1057-1085. [CrossRef]

15. Desjean-Perrotta, B.; Moseky, C.; Cantu, L.E. Preservice teachers' perceptions of the environment: Does ethnicity or dominant residential experience matter? J. Environ. Educ. 2008, 39, 21-32. [CrossRef]

16. Hungerford, H. Environmental education (EE) for the 21st century: Where have we been? Where are we now? Where are we headed? J. Environ. Educ. 2009, 41, 1-6. [CrossRef]

17. Yavetz, B.; Goldman, D.; Pe'er, S. Environmental literacy of pre-service teachers in Israel: A comparison between students at the onset and end of their studies. Environ. Educ. Res. 2009, 15, 393-415. [CrossRef]

18. Campbell, B.; Davies, I. Education and green citizenship: An exploratory study with student teachers. J. Furth. High. Educ. 1995, 19, 20-31. [CrossRef]

19. Dobson, A. Environmental Citizenship and Pro-Environmental Behaviour; Rapid research and evidence review; Sustainable Development Research Network: London, UK, 2010.

20. Hadjichambis, A.C.; Paraskeva-Hadjichambi, D. Education for Environmental Citizenship: The Pedagogical Approach. In Conceptualizing Environmental Citizenship for 21st Century Education; Springer: Cham, Switzerland, 2020.

21. Barry, J. Resistance is fertile: From environmental to sustainability citizenship. Environ. Citizsh. 2006, 21, 21-48.

22. Jagers, S.C.; Matti, S. Ecological citizens: Identifying values and beliefs that support individual environmental responsibility among swedes. Sustainability 2010, 2, 1055-1079. [CrossRef]

23. Cutter-Mackenzie, A.; Smith, R. Ecological literacy: The 'missing paradigm' in environmental education (part one). Environ. Educ. Res. 2003, 9, 497-524. [CrossRef]

24. Gebbels, S.; Evans, S.M.; Delany, J.E. Promoting environmental citizenship and corporate social responsibility through a school/industry/university partnership. J. Biol. Educ. 2011, 45, 13-19. [CrossRef]

25. Clarke, L.; Agyeman, J. Shifting the Balance in Environmental Governance: Ethnicity, Environmental Citizenship and Discourses of Responsibility. Antipode 2011, 43, 1773-1800. [CrossRef]

26. Gilbert, L.; Phillips, C. Practices of urban environmental citizenships: Rights to the city and rights to nature in Toronto. Citizsh. Stud. 2003, 7, 313-330. [CrossRef] 
27. Smederevac-Lalic, M.; Finger, D.; Kovách, I.; Lenhardt, M.; Petrovic, J.; Djikanovic, V.; Conti, D.; Boeve-de Pauw, J. Knowledge and Environmental Citizenship. In Conceptualizing Environmental Citizenship for 21st Century Education; Springer: Cham, Switzerland, 2020; pp. 69-82.

28. Ellis, R.; Waterton, C. Environmental citizenship in the making: The participation of volunteer naturalists in UK biological recording and biodiversity policy. Sci. Public Policy 2004, 31, 95-105. [CrossRef]

29. Martinho, A.P.; Nicolau, P.B.; Caeiro, S.; Amador, F.; Oliveira, C. Environmental Citizenship and Participation the Role of Education Programs. In Proceedings of the 14th European Roundtable on Sustainable Consumption and Production (ERSCP) conference and the 6th Environmental Management for Sustainable Universities (EMSU) conference, Delft, The Netherlands, 25-29 October 2010; pp. 1-17.

30. Takahashi, B.; Tandoc, E.C.; Duan, R.; Van Witsen, A. Revisiting environmental citizenship: The role of information capital and media use. Environ. Behav. 2017, 49,111-135. [CrossRef]

31. Environmental Evidence Australia (EEA). A review of best practice in environmental citizenship models. A review of best practice in environmental citizenship models; Environmental Evidence Australia: Victoria, Australia, 2012.

32. European Environment Agency (EEA). Material Resources and Waste-2012 Update. The European Environment. State and Outlook 2010. Eur. Environ. Agency Cph. 2012, 50.

33. Hadjichambis, A.; Reis, P. European Network for Environmental Citizenship (ENEC). Impact 2018, 2018, 52-54. [CrossRef]

34. European Network for Environmental Citizenship (ENEC). Available online: https:/ / enec-cost.eu/ (accessed on 17 November 2020).

35. Carlsson, M.; Jensen, B.B. Encouraging environmental citizenship: The roles and challenges for schools. In Environmental Citizenship: Getting from here to there; MIT press: Cambridge, MA, USA, 2006; pp. 237-261.

36. Gough, S.; Scott, W. Promoting environmental citizenship through learning: Toward a theory of change. In Environmental Citizenship: Getting from here to there; MIT press: Cambridge, MA, USA, 2006; pp. 263-285.

37. Schild, R. Environmental citizenship: What can political theory contribute to environmental education practice? J. Environ. Educ. 2016, 47, 19-34. [CrossRef]

38. Roczen, N.; Kaiser, F.G.; Bogner, F.X.; Wilson, M. A Competence Model for Environmental Education. Environ. Behav. 2014, 46, 972-992. [CrossRef]

39. Olsen, S.K.; Miller, B.G.; Eitel, K.B.; Cohn, T.C. Assessing teachers' environmental citizenship based on an adventure learning workshop: A case study from a social-ecological systems perspective. J. Sci. Teach. Educ. 2020, 31, 869-893. [CrossRef]

40. Álvarez-García, O.; Sureda-Negre, J.; Comas-Forgas, R. Environmental education in pre-service teacher training: A literature review of existing evidence. J. Teach. Educ. Sustain. 2015, 17, 72-85. [CrossRef]

41. Bascopé, M.; Perasso, P.; Reiss, K. Systematic review of education for sustainable development at an early stage: Cornerstones and pedagogical approaches for teacher professional development. Sustainability 2019, 11, 719. [CrossRef]

42. Ferreira, J.A.; Ryan, L.; Tilbury, D. Mainstreaming education for sustainable development in initial teacher education in Australia: A review of existing professional development models. J. Educ. Teach. 2007, 33, 225-239. [CrossRef]

43. Jeronen, E.; Palmberg, I.; Yli-Panula, E. Teaching methods in biology education and sustainability education including outdoor education for promoting sustainability-A literature review. Educ. Sci. 2017, 7, 1. [CrossRef]

44. PRISMA. Available online: http:/ / prisma-statement.org/ (accessed on 30 September 2020).

45. Cooper, H.M. Scientific guidelines for conducting integrative research reviews. Rev. Educ. Res. 1982, 52, 291-302. [CrossRef]

46. Boyatzis, R. Thematic Analysis and Code Development; Sage: Thousand Oaks, CA, USA, 1998; Volumes X-XI, ISBN 0761909613.

47. Braun, V.; Clarke, V. Using thematic analysis in psychology. Qual. Res. Psychol. 2006, 3, 77-101. [CrossRef]

48. Fereday, J.; Muir-Cochrane, E. Demonstrating rigor using thematic analysis: A hybrid approach of inductive and deductive coding and theme development. Int. J. Qual. Methods 2006, 5, 80-92. [CrossRef]

49. Mullet, D.R.; Willerson, A.; Lamb, K.N.; Kettler, T. Examining teacher perceptions of creativity: A systematic review of the literature. Think. Ski. Creat. 2016, 21, 9-30. [CrossRef]

50. Margot, K.C.; Kettler, T. Teachers' perception of STEM integration and education: A systematic literature review. Int. J. Stem Educ. 2019, 6, 1-16. [CrossRef]

51. Aarnio-Linnanvuori, E. How do teachers perceive environmental responsibility? Environ. Educ. Res. 2019, 25, 46-61. [CrossRef]

52. Avriel-Avni, N.; Gan, D. Nurturing environmental citizenship by mapping the field of action. Int. J. Sustain. High. Educ. 2019, 20, 985-1001. [CrossRef]

53. Chaya, J.K.; Abou Ali, I. The Effect of Environmental Project Based Learning on Increasing pre Service Teachers' Green-Citizenship. Available online: http:/ / search.shamaa.org/FullRecord?ID=124918 (accessed on 26 October 2020).

54. Gooch, M.; Rigano, D.; Hickey, R.; Fien, J. How do primary pre-service teachers in a regional Australian university plan for teaching, learning and acting in environmentally responsible ways? Environ. Educ. Res. 2008, 14, 175-186. [CrossRef]

55. Karatekin, K. Model review related to the effects of teachers' levels of ecological citizenship. Int. Electron. J. Environ. Educ. 2019, 9, 46-61.

56. Lummis, G.W.; Morris, J.E.; Lock, G.; Odgaard, J. The influence of ecological citizenship and political solidarity on Western Australian student teachers' perceptions of sustainability issues. Int. Res. Geogr. Environ. Educ. 2017, 26, 135-149. [CrossRef]

57. Spektor-Levy, O.; Abramovich, A. From "Hesitant" to "Environmental Leader": The influence of a professional development program on the environmental citizenship of preschool teachers. Eurasia J. Math. Sci. Technol. Educ. 2017, 13, 649-671. [CrossRef] 
58. Paige, R.M.; Cogan, J.J. Teachers' perceptions of citizen characteristics and environmental concerns in Minnesota, Hong Kong, and Guangdong: A comparative study. Pac. Asian Educ. J. 2002, 14, 17-35.

59. Ünal, E. The investigation of ecological citizenship levels of teacher candidates. Asian J. Educ. Train. 2019, 5, 329-334. [CrossRef]

60. Abd-El-Aal, W.M.M.; Steele, A. Practising environmental citizenship in Egypt: Hopes and challenges encountered. J. Educ. Sustain. Dev. 2013, 7, 183-204. [CrossRef]

61. Bradbery, D. Bridges to global citizenship: Ecologically sustainable futures utilising children's literature in teacher education. Aust. J. Environ. Educ. 2013, 29, 221-237. [CrossRef]

62. Gal, A.; Gan, D. Transformative sustainability education in Higher Education: Activating environmental understanding and active citizenship among professional studies learners. J. Transform. Educ. 2020, 18, 271-292. [CrossRef]

63. Hayward, B. Children, Citizenship and Environment: Nurturing A Democratic Imagination in A Changing World; Earthscan: Oxon, NY, USA, 2012; ISBN 9780203106839.

64. Kennedy, E.H.; Boyd, A. Gendered citizenship and the individualization of environmental responsibility: Evaluating a campus common reading program. Environ. Educ. Res. 2018, 24, 191-206. [CrossRef]

65. Hadjichambis, A.; Reis, P.; Paraskeva-Hadjichambi, D.; Činčera, J.; Boeve-de Pauw, J.; Gericke, N.; Knippels, M.C. Conceptualizing Environmental Citizenship for 21st Century Education; Springer: Cham, Switzerland, 2020; Volume 4, ISBN 978-3-030-20248-4.

66. Stables, A.; Scott, W. The quest for holism in education for sustainable development. Environ. Educ. Res. 2002, 8, 53-60. [CrossRef]

67. Petocz, P.; Reid, A. Enhancing Learning Using Generic and Specific Aspects of Knowledge Formation. In Proceedings of the 4th World Conference of the International Consortium for Educational Development (ICED): Spheres of Influence: Ventures and Visions in Educational Development, Perth, Western Australia, 3-6 July 2002.

68. Feldman, K.A. The perceived instructional effectiveness of college teachers as related to their personality and attitudinal characteristics: A review and synthesis. Res. High. Educ. 1986, 24, 139-213. [CrossRef]

69. Hopper, S.B. The Relationship of Personality Traits to Teacher Candidate Perceptions of Teaching Confidence and Teaching Experience in a Simulated Classroom Environment. Ph.D. Thesis, University of North Texas, Denton, TX, USA, 2014. Available online: https:/ /digital.library.unt.edu/ark:/67531/metadc500089/m2/1/high_res_d/dissertation.pdf (accessed on 26 October 2020).

70. Mullola, S.; Ravaja, N.; Lipsanen, J.; Alatupa, S.; Hintsanen, M.; Jokela, M.; Keltikangas-Järvinen, L. Gender differences in teachers' perceptions of students' temperament, educational competence, and teachability. Br. J. Educ. Psychol. 2012, 82, 185-206. [CrossRef] [PubMed]

71. Rahimi, S. An investigation into the effect of individual differences on Iranian EFL Teachers' perceptions concerning professional development obstacles. Theory Pract. Lang. Stud. 2017, 7, 570. [CrossRef]

72. Kibert, N.C. An Analysis of the Correlations between Attitude, Behavior and Knowledge Components of Environmental Literacy in Undergraduate University Students. Available online: https:/ / ufdc.ufl.edu/uf00100691/00001 (accessed on 26 October 2020).

73. McBeth, W.; Volk, T. The national environmental literacy project: A baseline study of middle grade students in the United States. J. Environ. Educ. 2009, 41, 55-67. [CrossRef]

74. UNESCO. Shaping the Future We Want UN Decade of Education for Sustainable Development; 2005-2014 Final Report; UNESCO: Paris, France, 2014; ISBN 9789231000539.

75. United Nations. The Sustainable Development Goals Report 2016; United Nations: New York, NY, USA, 2016.

76. Kansanen, P.; Tirri, K.; Meri, M.; Krokfors, L.; Husu, J.; Jyrhämä, R. Teachers' pedagogical thinking: Theoretical landscapes, practical challenges; Peter Lang Inc.: New York, NY, USA, 2000.

77. Cotton, D.R.E. Implementing curriculum guidance on environmental education: The importance of teachers' beliefs. J. Curric. Stud. 2006, 38, 67-83. [CrossRef] 